\title{
Hydrogeochemistry and surface water quality assessment of IB valley coalfield area, India
}

\author{
Bishnu Prasad Sahoo ${ }^{1,2}$ [D $\cdot$ Himanshu Bhushan Sahu ${ }^{1}\left[\right.$. Dhruti Sundar Pradhan ${ }^{1,3}$
}

Received: 9 December 2019 / Accepted: 18 May 2021 / Published online: 25 August 2021

(c) The Author(s) 2021

\begin{abstract}
Coal mining and ancillary activities have the potential to cause water pollution characterized by acid mine drainage, acid mine leachates, extreme $\mathrm{pH}$ conditions and heavy metal contaminations. In the present work, 33 water samples in premonsoon and 34 water samples in monsoon were collected from the surface water bodies of Ib Valley coalfield, India for hydrogeochemical analysis. In premonsoon, pH, TSS, Turbidity, DO, BOD, COD, Magnesium, Cadmium, Selenium, Nickel, Aluminum and in monsoon, pH, TSS, Turbidity, DO, BOD, COD, Iron, Cadmium, Selenium, Nickel and Aluminum were nonconforming to the permissible limit set by the Bureau of Indian Standards, World Health Organisation and Ministry of Environment, Forest and Climate Change, Government of India. The average BOD/COD ratio of less than 0.6 in both seasons indicated $\mathrm{Ib}$ valley coalfield water was not fairly biodegradable. The analysis of variance (ANOVA) revealed that significant seasonal variation $(p<0.05)$ was observed in the hydro-chemical parameters viz. TSS, turbidity, redox potential, acidity, total hardness, bicarbonate alkalinity, chloride, sulfate, nitrate, sodium, calcium, magnesium, iron, cadmium, chromium and magnesium during the entire sampling period. Whereas, no significant seasonal variation $(p>0.05)$ was observed in $\mathrm{pH}, \mathrm{EC}$, TDS, DO, BOD, residual chlorine, COD, oil and grease, fluoride, potassium, zinc, copper, selenium, nickel, aluminum, boron, silica, temperature, salinity, cyanide and phenol. Water Quality Index revealed that 39.39\% and $35.29 \%$ samples belong to poor water quality category in premonsoon and monsoon, respectively. As per Heavy Metal Pollution Index, Degree of Contamination $(\mathrm{Cd})$ and Heavy metal evaluation index, medium degree of pollution were exhibited by $51.52 \%, 30.30 \%$ and $45.45 \%$ samples in premonsoon and 20.59\%,35.29\% and 26.47\% samples in monsoon. Whereas, 5.88\%, 2.94\% and 5.88\% samples were having high degree of pollution in monsoon and $15.15 \%$ samples caused high degree of pollution with respect to $\mathrm{Cd}$ in premonsoon. However, EC, Na\%, PI, SAR and RSC values suggested that the water can be used for irrigation. Water type of the region had been found to be $\mathrm{Ca}-\mathrm{Mg}-\mathrm{Cl}-\mathrm{SO}_{4}$ by Piper diagram.
\end{abstract}

Keywords Ib valley coalfield $\cdot$ Coal mining $\cdot$ Water quality index $\cdot$ Heavy metal pollution index $\cdot$ Degree of contamination . Heavy metal evaluation index

Bishnu Prasad Sahoo

bishnu89sm@gmail.com

$\triangle$ Himanshu Bhushan Sahu

hbsahu@gmail.com; hbsahu@nitrkl.ac.in

Dhruti Sundar Pradhan

dspradhan000@gmail.com

1 Department of Mining Engineering, National Institute of Technology, Rourkela 769 008, India

2 Central Pollution Control Board, East Regional Directorate, Ministry of Environment, Forest and Climate Change, Kolkata 700107, India

3 Department of Mining Engineering, Indian Institute of Technology, Kharagpur 721 302, India

\section{Introduction}

Coal continues to be one of the major sources of non-renewable energy. To meet the increased demand for industrial sectors such as steel, power, cement there is a continuous increase in coal production in our country, and there is greater stress on opencast mines to achieve the target. Coal mining is carried out broadly by two methods, viz. opencast and underground mining. Opencast mining technique is the preferred method and contributed to $91.22 \%$ of India's total coal production in 2013-2014 (Provisional Coal Statistics 2013-2014). The total production of coal for 2016-2017 was estimated at 724.71MT (Ministry of Coal 2016-2017). With increase in depth of mine, the workings in many opencast 
mines extend below the water table. The mine excavations, therefore, are normally associated with a high degree of water influx due to the ingress of groundwater. A large quantity of water also accumulates in the deep part of the mines or mine sumps during monsoon. The mine waters in many mines is usually pumped and discharged outside the mine boundary, which end up in polluting the nearby water bodies. The water in Jharia, Raniganj and Northeastern Coalfields was found to be contaminated with high amount of sulfate (Singh 1988). Tiwary and Dhar (1994) observed that the key pollutants connected with coal mines were suspended solids, dissolved solids, acidity and iron compounds. Pathak and Banerjee (1992) studied water quality in Chapha incline of Umaria coalfield in eastern Madhya Pradesh and found that the mine water was severely polluted with turbidity, BOD and bacterial colonies. The acidity in acid mine drainage is caused by hydrolysis of dissolved $\mathrm{Fe}$ (II), $\mathrm{Fe}$ (III), Al, and Mn (II), as well as the precipitation of associated solid hydroxide substances. The $\mathrm{pH}$ and concentrations of alkalinity, acidity, and metals such as Fe, Mn, and $\mathrm{Al}$, in mine discharge and receiving aquatic system usually determine possible environmental hazards, corrosiveness and water toxicity (Environmental Protection Agency 2000). Effluent from Mines if found suitable can be utilized for irrigation. However, the high salt content in mine water causes an increase in soil solution osmotic pressure. A high salt concentration (high EC) in water leads to the formation of saline soil, while high sodium concentration leads to the development of alkaline soil. The salts besides affecting the growth of the plants directly, also affect the soil structure, permeability and aeration, which indirectly affect the plant growth (Singh 2011). Therefore, proper scientific investigation is necessary to ensure mine water is safe for irrigation. To assess the water quality for irrigation purpose, TDS, Electrical conductivity, Sodium absorption ratio (SAR), Percent sodium (\%Na), Residual sodium carbonate (RSC), Permeability index (PI), Kelley index (KI) and Magnesium hazard $(\mathrm{MH})$ are required to be examined.

The Odisha State Pollution Control Board has now made it mandatory for all the operating mines to follow "zero liquid discharge" concept. This means that the water has to be stored within the mine boundary and reused for different mining applications such as dust suppression, firefighting, plantation activities. However, if it is not feasible, then the water can be discharged outside only after proper treatment; and installation of the online real-time water quality monitoring system at the point of discharge. In monsoon, the rainfall occurs over the entire lease area. A part of it infiltrates downwards into the water table, a lesser amount evaporates to the atmosphere, and the rest contributes to the surface runoff. Unless specific arrangements have been made, the surface runoff of the region takes its usual course moving through the overburden (OB) dumps, coal stocks, workshops and railway sidings, etc., into the nearby water bodies. Untreated mine water and Leaching of the mine wastes can affect the hydrological system and disrupt the ecosystem. This research aims to assess the seasonal variations in concentrations of various water quality parameters in mines sumps, treatment plants, river and ponds to ascertain the suitability of water for drinking and irrigation.

\section{Study area}

The state of Odisha in India has two major coalfields, viz. Talcher and Ib Valley, which are under the administrative control of Mahanadi Coalfields Limited, a subsidiary of the public sector enterprise Coal India Ltd. It has a coal reserve of 22.3 billion tonnes, the third highest in the country. Ib Valley Coalfield is located between latitudes $21^{\circ} 41^{\prime} \mathrm{N}$ and $22^{\circ} 06^{\prime} \mathrm{N}$ and longitudes $83^{\circ} 30^{\prime} \mathrm{E}$ and $84^{\circ} 08^{\prime} \mathrm{E}$ with an area of 1,375 square kilometers (531 sq. mi). It covers part of Jharsuguda, and Sundargarh districts of the state Odisha, India (Fig. 1). Currently, there are five opencast and three underground mines in operation in the Ib valley area, and two opencast mines in Basundhra area in this coalfield. The Ib-valley coalfield is a part of the NE-SW chief basin belt of the Son-Mahanadi valley. The location map of study area was prepared using the ArcGIS 10.5. software.

\section{Geology}

Ib Valley Coalfield is a portion of large synclinal Gondwana basin of Raigarh-Hingir and Chhattisgarh Coalfields. The stratigraphic progression (Table 1) begins with Precambrian rocks at the base followed by an unconformity. Gondwana supergroups such as Talchir, Karharabari, Barakar, lower Kamthi (Raniganj) of Permian time and upper Kamthi Formation of Triassic time lie over the unconformity and Precambrian rocks. At the top recent and subrecent, deposits are found (Goswami et al. 2006; Senapati 2015).

The chief coal-bearing formations in the Ib Valley coalfield area are Barakar and Karharbari of lower Permian age. Barakar formation has around twenty carbonaceous horizons. These horizons after being clubbed together are recognized into five seams, viz. Belpahar, Parkhani, Lajkura, Rampur, and $\mathrm{Ib}$. Parkhani seam is very poor in quality and thickness and is usually not considered as mineable. Belpahar seam is situated in the deep side of Lakhanpur OCP, and in this seam, mining operation is not expected in near future. Karharbari formation holds only thin coal bands below $\mathrm{Ib}$ river (Senapaty and Behera 2015). The two predominant seams being mined in this coalfield, therefore, are Lajkura and Rampur. 

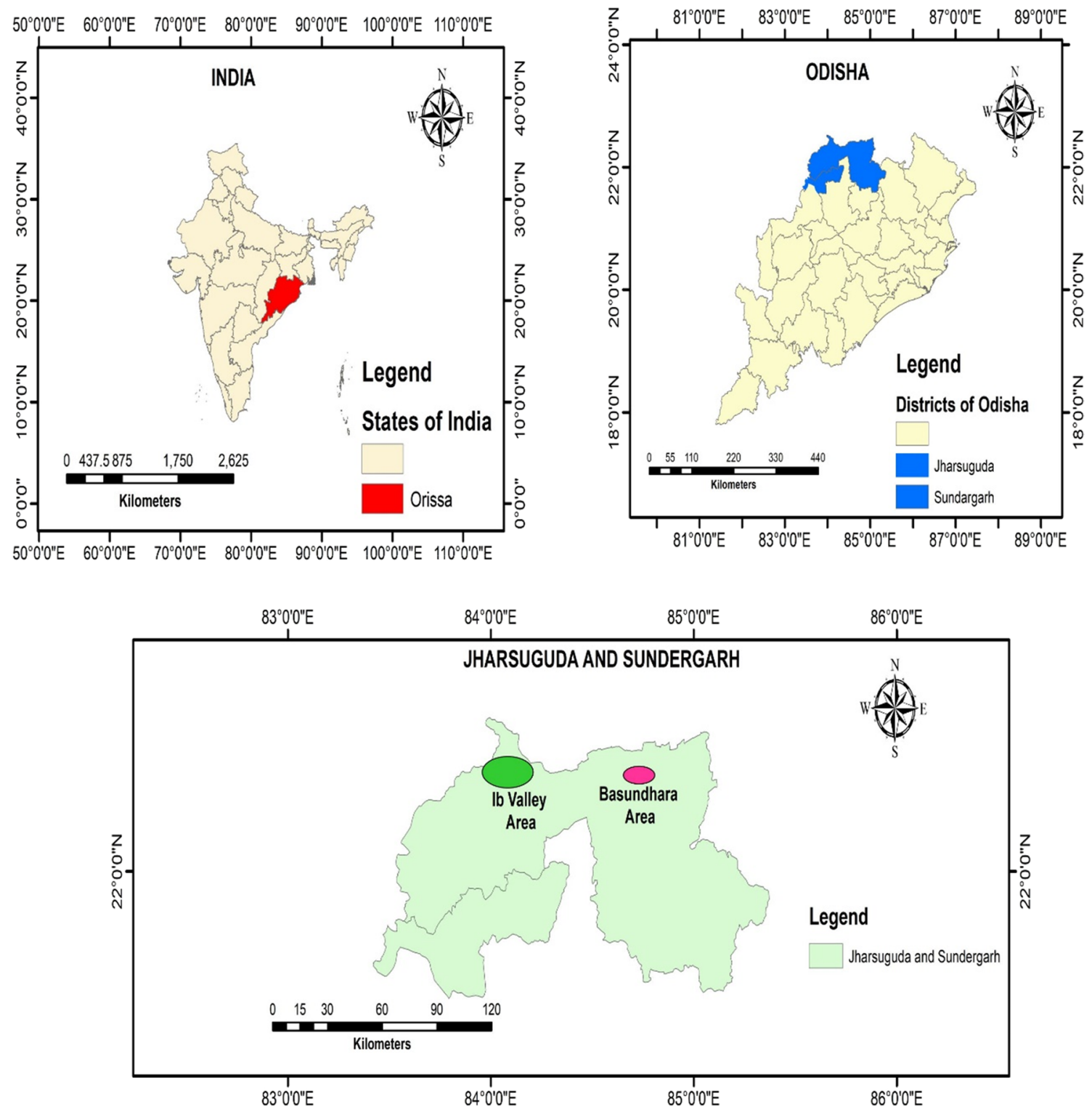

Fig. 1 Location Map showing India, Odisha, Jharsuguda, Sundergarh, Ib Valley area and Basundhara area

\section{Drainage and hydrogeology}

The study area is tropical and comes across three seasons, viz. summer, monsoon and winter. The average annual rainfall is around $1527 \mathrm{~mm}$. The monsoon season usually lasts from June to September. Tropical rain forest type natural vegetation is predominant in this area (Odisha State Pollution Control Board 2010). The Mahanadi river system along with its tributary Ib and Hirakud reservoir is the chief aquatic body in Ib Valley and Jharsuguda area. They provide huge water supply and carry waste and effluent load from this area. Three streams namely Lilary, Bhenden and Kharkhari in the area usually get discharged water from various industries, mines, domestic and agricultural sector.
Runoff during monsoon from various stockpiles such as coal, mineral, solid waste gets down to the stream network which ultimately drains into the Hirakud reservoir. The critical water quality parameters in the surface as well as groundwater are found to be fluoride, mercury, cadmium and BOD (Odisha State Pollution Control Board 2010). The hydrogeology of the area consists of Consolidated Formation, SemiConsolidated Formation and Unconsolidated Formation.

\section{Consolidated formation}

About $60 \%$ of the area is underlain by consolidated formations comprising Precambrian metasediment of Sambalpur series, Iron ore and Gangpur series. These rocks 
Table 1 Geological succession of the Ib-valley coalfield (Goswami et al. 2006; Senapaty and Behera 2015)

\begin{tabular}{|c|c|c|c|}
\hline Age & Formations & Lithology & Thickness in meter \\
\hline Recent & Alluvium/ Laterite & $\begin{array}{l}\text { Alluvium; Sand, silt and clay of older alluvium, younger } \\
\text { floodplain deposits, channel fills, etc }\end{array}$ & - \\
\hline Sub-Recent & & Laterites/ Recent gravel and conglomerate beds & \\
\hline \multirow{2}{*}{$\begin{array}{l}\text { Upper and middle } \\
\text { Permian to Lower } \\
\text { Triassic }\end{array}$} & Kamthi $($ Upper $)=$ Raniganj & $\begin{array}{l}\text { Conglomerates, Pebbly and ferruginous sandstones and red } \\
\text { shales }\end{array}$ & $>180$ \\
\hline & Kamthi $($ Lower $)=$ Barren measures & $\begin{array}{l}\text { Gray shales, Carbonaceous shales, sandstone, clay, and iron- } \\
\text { stone nodules }\end{array}$ & $>250$ \\
\hline \multirow[t]{3}{*}{ Lower Permian } & Barakar & $\begin{array}{l}\text { Gray sandstone, carbonaceous Shale, siltstone with thick coal } \\
\text { seams and fire clay }\end{array}$ & $350-500$ \\
\hline & Karharbari & Black carbonaceous sandstone, Pebble bed, coal seams & $30-65$ \\
\hline & Talchir & $\begin{array}{l}\text { Diamictite, greenish sandstone, olive and chocolate shales, } \\
\text { rhythmites }\end{array}$ & $>130$ \\
\hline \multicolumn{4}{|l|}{ UNCONFORMITY } \\
\hline Precambrian & & Granite gneisses, amphibolites, migmatites, etc & \\
\hline
\end{tabular}

are very hard and compact, and the groundwater occurs mainly in secondary porosity. Groundwater occurs under semiconfined to confined conditions in fractured rocks. Granite Gneisses are the most predominant rock types usually occupying the underlying plains and topographic lows. These rocks are highly weathered, and the thickness of the weathered zone usually ranges from 4.57 to $12.03 \mathrm{mbgl}$ and depth to water level from 3.91 to 9.92 and 1.36 to $6.69 \mathrm{mbgl}$ in premonsoon and postmonsoon, respectively. The specific capacity of open wells varies from 8.30 to $76.32 \mathrm{~m}^{3} / \mathrm{day} / \mathrm{m}$. The quartzite of the iron ore group is bedded, joined but having little groundwater development prospects. The depth of open wells varies from 6.94 to $9.37 \mathrm{mbgl}$ and depth to water level from 5.99 to 8.70 and 3.26 to $4.45 \mathrm{mbgl}$ in premonsoon and postmonsoon, respectively. The open wells are tested, and its capacity was found to be $10.46 \mathrm{~m}^{3} / \mathrm{day} / \mathrm{m}$. Mica schists have low permeability. The depth of the open wells ranges from 6.11 to $7.84 \mathrm{~m}$, and depth to water level varies from 4.12 . to 7.1 and 2.53 to $3.18 \mathrm{~m}$ in premonsoon and postmonsoon, respectively. The specific capacity of the open well tested was found to be of the order of $8.30 \mathrm{~m}^{3} / \mathrm{day} / \mathrm{m}$.

\section{Semi-consolidated formation}

Sandstones, shales, conglomerates grits, etc., belonging to Talcher, Barakar and Kamthis of lower Gondwanas constitute the semi-consolidated formations. The needle shales with a high frequency of intersecting joints form good aquifers. The depth of the open well varies from 6.6 to $12.5 \mathrm{mbgl}$. The premonsoon and postmonsoon water levels vary from 5.4 to 10.25 and 1.6 to $7.5 \mathrm{~m}$, respectively. The specific capacity is found to be $10.29 \mathrm{~m}^{3} /$ day $/ \mathrm{m}$.

\section{Unconsolidated formation}

Laterites and alluvium of sub-recent to recent age constitute the unconsolidated formations. Laterites that occur in patches as capping the older formations and form a very good shallow aquifer. The coarse grained sand with gravels and pebbles form repository of groundwater which occurs under water table conditions. Alluvium forms potential shallow aquifer to be developed through dug wells (Central Ground Water Board 2013).

\section{Materials and methods}

\section{Sampling}

The Ib Valley Coalfield area has been classified into two different areas, viz. Ib Valley area and Basundhara area. Ib Valley is further classified into Samaleswari area and Lakhanpur area. Samaleswari area has two opencast projects (OCP) such as Samaleswari and Lajkura. Pandenjhor and Bagmara nallah make their course to Ib river through this zone (Fig. 2). Similarly, Lakhanpur area has three opencast projects viz. Lakhanpur, Belpahar and Lilari. Lilari nallah and puljari nallah are flowing in this region (Fig. 2). Basundhara area has two opencast projects viz. Basundhara and Kulda. Basundhara river and Basundhara nallah flow in this area (Fig. 3). A total of 77 numbers of water samples, of which 33 samples were collected during premonsoon (April-May) and 34 samples were collected during monsoon (June-July) period in 2015 for analysis. These samples were collected from the mine sumps, inlet and outlet of effluent treatment plants (ETPs), inlet and outlet of mine discharge treatment plant (MDTP) from 7 different mines as mentioned earlier. Additionally, water 
Fig. 2 Drainage pattern in Ib valley area
Fig. 3 Drainage pattern in Basundhara area
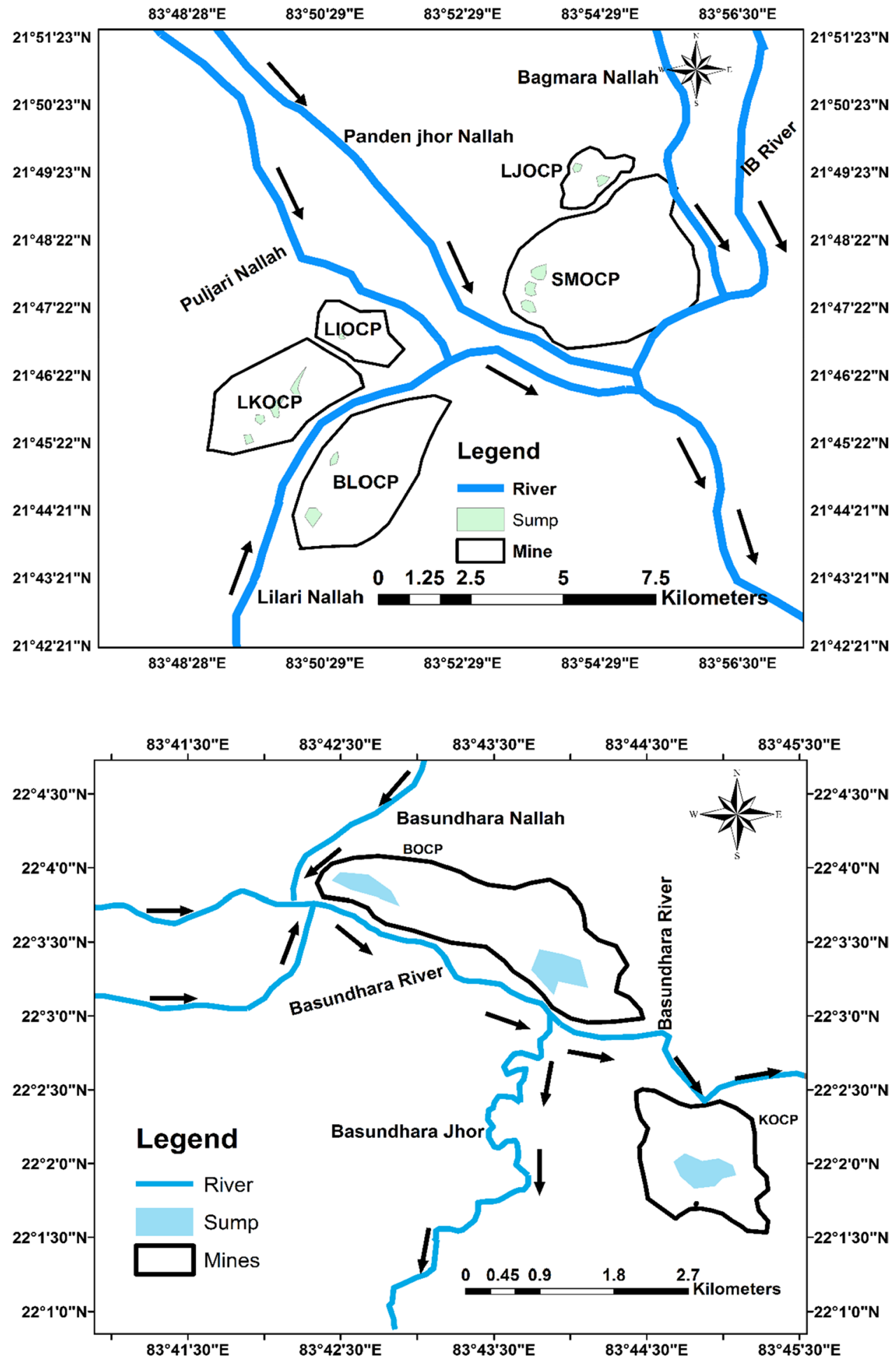

samples were also collected, from the upstream, downstream and confluence points of nallahs and rivers where mine water are discharged, in order to study the pollution load carried out by these drains.

The details of the water sampling sources are presented in Table 2. The maps of the water sampling locations of the area are presented in Figs. 4 and 5.

\section{Analytical methodology}

For water quality analysis, the sampling bottles were thoroughly cleaned with 1:3 nitric acid and distilled water solution followed by twice with double distilled water and finally rinsed with water sample to be collected. Grab 
Table 2 Details of water sampling locations and sources of Ib Valley Coalfield

\begin{tabular}{|c|c|c|c|c|c|c|}
\hline Name of the coalfield & Name of the area & Sample No & $\begin{array}{l}\text { Sampling Point description } \\
\text { for both Premonsoon and } \\
\text { monsoon }\end{array}$ & Source & Sample codes & Coordinates \\
\hline \multirow[t]{25}{*}{$\begin{array}{l}\text { Ib Valley Coalfield } \\
\text { Area }\end{array}$} & \multirow[t]{9}{*}{ Basundhara Area } & 1 & $\begin{array}{l}\text { Basundhara Nallah Down- } \\
\text { stream }\end{array}$ & Nallah/Stream & BSND & $\begin{array}{l}\text { N } 22^{\circ} 03^{\prime} 57.2^{\prime \prime} \\
\text { E } 83^{\circ} 42^{\prime} 12.4^{\prime \prime}\end{array}$ \\
\hline & & 2 & Basundhara Nallah Upstream & Nallah/Stream & BSNU & $\begin{array}{l}\text { N } 22^{\circ} 04^{\prime} 6.40^{\prime \prime} \\
\text { E } 83^{\circ} 42^{\prime} 16.8^{\prime \prime}\end{array}$ \\
\hline & & 3 & Basundhara OCP West Sump & Sump & BSWS & $\begin{array}{l}\text { N } 22^{\circ} 03^{\prime} 50.9^{\prime \prime} \\
\text { E } 83^{\circ} 42^{\prime} 29.8^{\prime \prime}\end{array}$ \\
\hline & & 4 & Basundhara OCP East Sump & Sump & BSEC & $\begin{array}{l}\text { N } 22^{\circ} 03^{\prime} 9.5^{\prime \prime} \\
\text { E } 83^{\circ} 43^{\prime} 56.1^{\prime \prime}\end{array}$ \\
\hline & & 5 & $\begin{array}{l}\text { Basundhara OCP Oil Trap } \\
\text { Inlet }\end{array}$ & ETP & BOTI & $\begin{array}{l}\text { N } 22^{\circ} 03^{\prime} 34.2^{\prime \prime} \\
\text { E } 83^{\circ} 43^{\prime} 53.1^{\prime \prime}\end{array}$ \\
\hline & & 6 & $\begin{array}{l}\text { Basundhara OCP Oil Trap } \\
\text { Outlet }\end{array}$ & ETP & ВOTO & $\begin{array}{l}\text { N } 22^{\circ} 03^{\prime} 35.9^{\prime \prime} \\
\text { E } 83^{\circ} 43^{\prime} 53.0^{\prime \prime}\end{array}$ \\
\hline & & 7 & $\begin{array}{l}\text { Basundhra River Down- } \\
\text { stream near Kulda OCP }\end{array}$ & River & KD & $\begin{array}{l}\text { N } 22^{\circ} 02^{\prime} 25.4^{\prime \prime} \\
\text { E } 83^{\circ} 44^{\prime} 52.7^{\prime \prime}\end{array}$ \\
\hline & & 8 & Kulda OCP MDTP Outlet & Mine Discharge & KMO & $\begin{array}{l}\mathrm{N} 22^{\circ} 02^{\prime} 11.4^{\prime \prime} \\
\mathrm{E} 83^{\circ} 45^{\prime} 0.3^{\prime \prime}\end{array}$ \\
\hline & & 9 & Kulda Mine Sump & Sump & KMS & $\begin{array}{l}\text { N } 22^{\circ} 01^{\prime} 54.7^{\prime \prime} \\
\text { E } 83^{\circ} 44^{\prime} 43.2^{\prime \prime}\end{array}$ \\
\hline & \multirow[t]{11}{*}{$\begin{array}{l}\text { Ib Valley Area } \\
\text { (Samaleswari } \\
\text { area) }\end{array}$} & 10 & $\begin{array}{l}\text { Samaleswari OCP Railway } \\
\text { Siding Inlet }\end{array}$ & Railway Siding & SRSI & $\begin{array}{l}\text { N } 21^{\circ} 49^{\prime} 16.4^{\prime \prime} \\
\text { E } 83^{\circ} 54^{\prime} 52.0^{\prime \prime}\end{array}$ \\
\hline & & 11 & $\begin{array}{l}\text { Samaleswari OCP Railway } \\
\text { Siding Outlet }\end{array}$ & Railway Siding & SRSO & $\begin{array}{l}\text { N } 21^{\circ} 49^{\prime} 15.2^{\prime \prime} \\
\text { E } 83^{\circ} 54^{\prime} 51.2^{\prime \prime}\end{array}$ \\
\hline & & 12 & Samaleswari OCP Sump & Sump & SSS & $\begin{array}{l}\text { N } 21^{\circ} 47^{\prime} 55.2^{\prime \prime} \\
\text { E } 83^{\circ} 53^{\prime} 28.8^{\prime \prime}\end{array}$ \\
\hline & & 13 & Samaleswari OCP ETP Inlet & ETP & SEI & $\begin{array}{l}\text { N } 21^{\circ} 48^{\prime} 3.0^{\prime \prime} \\
\text { E } 83^{\circ} 54^{\prime} 30.1^{\prime \prime}\end{array}$ \\
\hline & & 14 & $\begin{array}{l}\text { Samaleswari OCP ETP } \\
\text { Outlet }\end{array}$ & ETP & SEO & $\begin{array}{l}\text { N } 21^{\circ} 48^{\prime} 3.0^{\prime \prime} \\
\text { E } 83^{\circ} 54^{\prime} 30.1^{\prime \prime}\end{array}$ \\
\hline & & 15 & $\begin{array}{l}\text { Samaleswari OCP MDTP } \\
\text { Inlet }\end{array}$ & Mine Discharge & SMI & $\begin{array}{l}\text { N } 21^{\circ} 47^{\prime} 58.7^{\prime \prime} \\
\text { E } 083^{\circ} 54^{\prime} 45.1^{\prime \prime}\end{array}$ \\
\hline & & 16 & $\begin{array}{l}\text { Samaleswari OCP MDTP } \\
\text { Outlet }\end{array}$ & Mine Discharge & SMO & $\begin{array}{l}\text { N } 21^{\circ} 47^{\prime} 54.2^{\prime \prime} \\
\text { E } 083^{\circ} 54^{\prime} 49.5^{\prime \prime}\end{array}$ \\
\hline & & 17 & $\begin{array}{l}\text { Samaleswari OCP MDTP } \\
\text { extended Pond Out- } \\
\text { let }(500 \mathrm{~m} \text { from existing } \\
\text { Outlet) }\end{array}$ & Mine Discharge & SMPI & $\begin{array}{l}\text { N } 21^{\circ} 47^{\prime} 29.9^{\prime \prime} \\
\text { E } 083^{\circ} 55^{\prime} 19.7^{\prime \prime}\end{array}$ \\
\hline & & 18 & Lajkura OCP Sump & Sump & $\mathrm{LS}$ & $\begin{array}{l}\text { N } 21^{\circ} 49^{\prime} 30.8^{\prime \prime} \\
\text { E } 083^{\circ} 54^{\prime} 07.4^{\prime \prime}\end{array}$ \\
\hline & & 19 & Lajkura OCP ETP Inlet & ETP & LJEI & $\begin{array}{l}\text { N } 21^{\circ} 49^{\prime} 30.2^{\prime \prime} \\
\text { E } 083^{\circ} 54^{\prime} 50.5^{\prime \prime}\end{array}$ \\
\hline & & 20 & Lajkura OCP ETP Outlet & ETP & LJEO & $\begin{array}{l}\text { N } 21^{\circ} 49^{\prime} 30.9^{\prime \prime} \\
\text { E } 083^{\circ} 54^{\prime} 50.8^{\prime \prime}\end{array}$ \\
\hline & \multirow[t]{5}{*}{$\begin{array}{l}\text { Ib Valley Area } \\
\text { (Lakhanpur Area) }\end{array}$} & 21 & Belpahar OCP ETP Inlet & ETP & BEI & $\begin{array}{l}\text { N } 21^{\circ} 45^{\prime} 40.6^{\prime \prime} \\
\text { E } 083^{\circ} 51^{\prime} 44.2^{\prime \prime}\end{array}$ \\
\hline & & 22 & Belpahar OCP ETP Outlet & ETP & BEO & $\begin{array}{l}\text { N } 21^{\circ} 45^{\prime} 40.9^{\prime \prime} \\
\text { E } 083^{\circ} 51^{\prime} 44.6^{\prime \prime}\end{array}$ \\
\hline & & 23 & Belpahar OCP MDTP Inlet & Mine Discharge & BMI & $\begin{array}{l}\text { N } 21^{\circ} 46^{\prime} 01.4^{\prime \prime} \\
\text { E } 083^{\circ} 51^{\prime} 42.7^{\prime \prime}\end{array}$ \\
\hline & & 24 & Belpahar OCP MDTP Outlet & Mine Discharge & $\mathrm{BMO}$ & $\begin{array}{l}\mathrm{N} 21^{\circ} 46^{\prime} 06.3^{\prime \prime} \\
\mathrm{E} 083^{\circ} 51^{\prime} 45.9^{\prime \prime}\end{array}$ \\
\hline & & 25 & Belpahar Mine Sump & Sump & BMS & $\begin{array}{l}\text { N } 21^{\circ} 44^{\prime} 17.8^{\prime \prime} \\
\text { E } 083^{\circ} 50^{\prime} 26.3^{\prime \prime}\end{array}$ \\
\hline
\end{tabular}


Table 2 (continued)

\begin{tabular}{|c|c|c|c|c|c|}
\hline Name of the coalfield Name of the area & Sample No & $\begin{array}{l}\text { Sampling Point description } \\
\text { for both Premonsoon and } \\
\text { monsoon }\end{array}$ & Source & Sample codes & Coordinates \\
\hline & 26 & Lilari Mine Sump & Sump & LIS & $\begin{array}{l}\text { N } 21^{\circ} 45^{\prime} 23.1^{\prime \prime} \\
\text { E } 083^{\circ} 52^{\prime} 53.16^{\prime \prime}\end{array}$ \\
\hline & 27 & Lilari Mine ETP outlet & ETP & LIEO & $\begin{array}{l}\text { N } 21^{\circ} 46^{\prime} 40.2^{\prime \prime} \\
\text { E } 083^{\circ} 51^{\prime} 24.6^{\prime \prime}\end{array}$ \\
\hline & 28 & $\begin{array}{l}\text { Lilari Nallah Downstream } \\
\text { near Belpahar OCP }\end{array}$ & Nallah/Stream & LIDB & $\begin{array}{l}\mathrm{N} 21^{\circ} 46^{\prime} 09.0^{\prime \prime} \\
\mathrm{E} 083^{\circ} 51^{\prime} 49.5^{\prime \prime}\end{array}$ \\
\hline & 29 & $\begin{array}{l}\text { Lilari Nallah Downstream } \\
\text { near lakhanpur OCP }\end{array}$ & Nallah/Stream & LIDL & $\begin{array}{l}\mathrm{N} 21^{\circ} 46^{\prime} 09.8^{\prime \prime} \\
\mathrm{E} 083^{\circ} 51^{\prime} 49.4^{\prime \prime}\end{array}$ \\
\hline & 30 & Lilari Nallah Upstream & Nallah/Stream & LIUP & $\begin{array}{l}\mathrm{N} 21^{\circ} 46^{\prime} 09.7^{\prime \prime} \\
\mathrm{E} 083^{\circ} 51^{\prime} 49.9^{\prime \prime}\end{array}$ \\
\hline & 31 & $\begin{array}{l}\text { Lakhanpur OCP Central } \\
\text { sump }\end{array}$ & Sump & LKCS & $\begin{array}{l}\mathrm{N} 21^{\circ} 45^{\prime} 28.3^{\prime \prime} \\
\mathrm{E} 083^{\circ} 49^{\prime} 18.0^{\prime \prime}\end{array}$ \\
\hline & 32 & Lakhanpur MDTP Inlet & Mine Discharge & LKMI & $\begin{array}{l}\text { N } 21^{\circ} 46^{\prime} 51^{\prime} 10.3^{\prime \prime} \\
\text { E } 083^{\circ} 51^{\prime} 02.0^{\prime \prime}\end{array}$ \\
\hline & 33 & Lakhanpur MDTP Outlet & Mine Discharge & LKMO & $\begin{array}{l}\mathrm{N} 21^{\circ} 46^{\prime} 12.9^{\prime \prime} \\
\mathrm{E} 083^{\circ} 50^{\prime} 10.0^{\prime \prime}\end{array}$ \\
\hline & 34 & $\begin{array}{l}\text { Puljari Nallah upstream } \\
\text { (Only for Monsoon) }\end{array}$ & Nallah/Stream & PNUS & $\begin{array}{l}\text { N } 21^{\circ} 45^{\prime} 47.2^{\prime \prime} \\
\text { E } 083^{\circ} 49^{\prime} 23.9^{\prime \prime}\end{array}$ \\
\hline
\end{tabular}

water sampling method was followed to collect the water sample. About $5 \mathrm{~L}$ of sub-surface water was collected by using a shallow water sampler. In situ temperature was recorded using a Brannan thermometer. Samples were collected in high-density polyethylene (HDPE) containers for the estimation of general parameters $(1 \mathrm{~L})$ and Biochemical Oxygen Demand (BOD) (2.5 L). Chemical oxygen demand (COD) samples were collected in
$100 \mathrm{~mL}$ pre-cleaned Nalgene bottles and preserved with $0.2 \mathrm{~mL}$ concentrated sulfuric acid to have Power of hydrogen $(\mathrm{pH}) \leq 2$. DO was fixed in situ with Winkler's reagents. Samples collected from Effluent treatment plant (ETP), Mine discharge treatment plant (MDTP), drains for ammonia were preserved with concentrated sulfuric acid. Samples for heavy metal analysis were preserved with concentrated nitric acid on the field to bring the $\mathrm{P}^{\mathrm{H}}$
Fig. 4 Map showing Ib valley area with location of sampling points

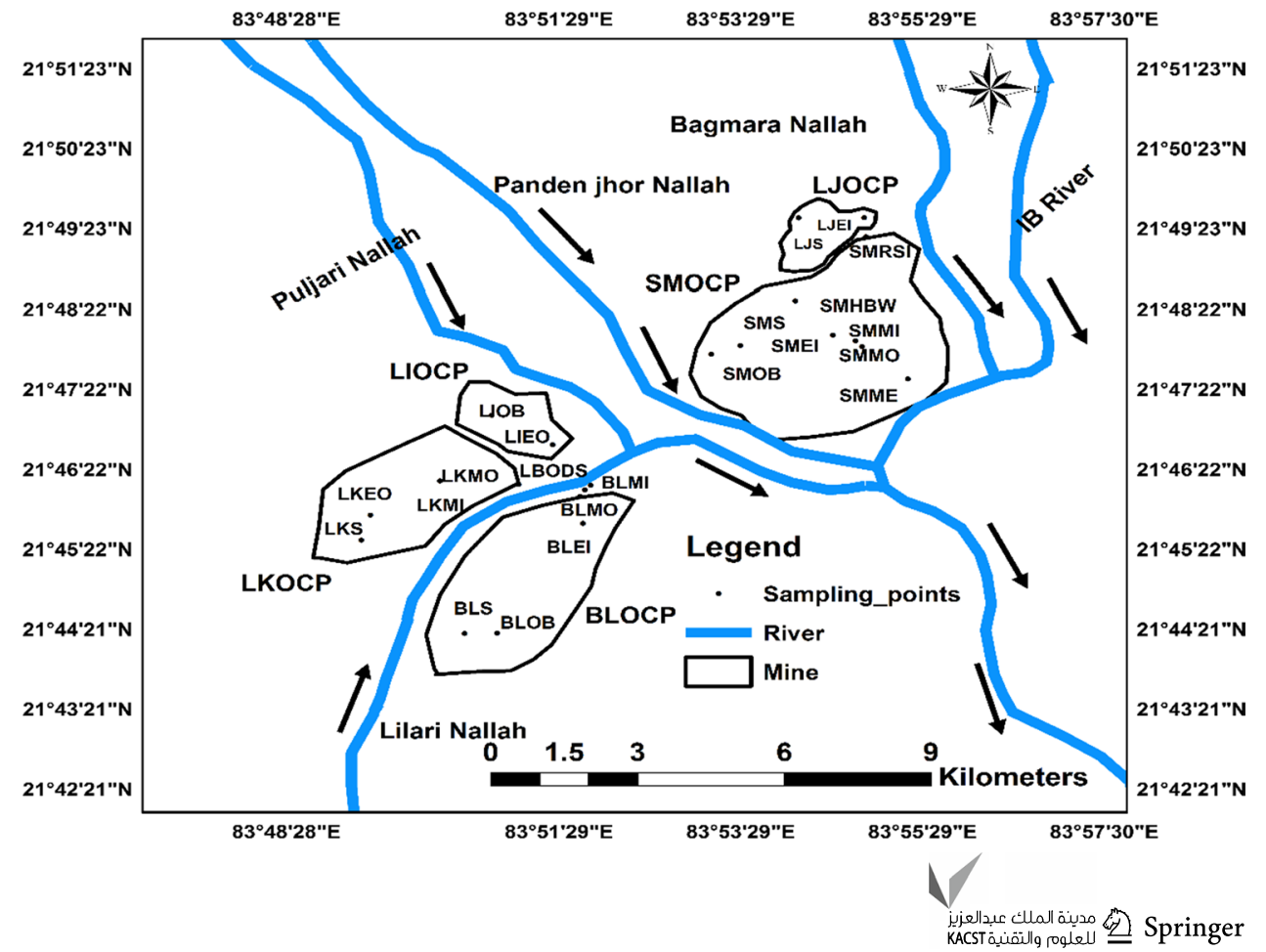


Fig. 5 Map showing Basundhara area with location of sampling points

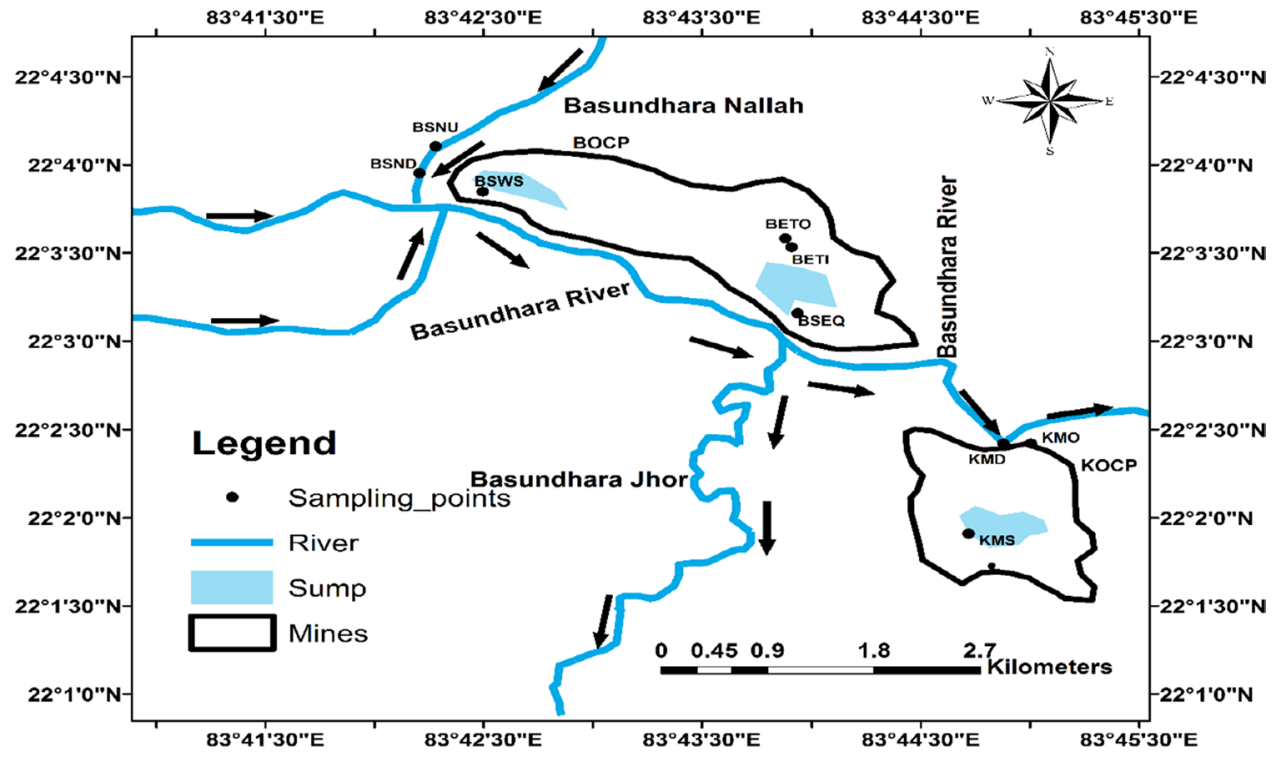

down to two in order to avoid metal precipitation. Samples for oil and grease were collected in 1 Litre amber bottle and preserved with concentrated hydrochloric acid in the field. All the samples were preserved at $4{ }^{\circ} \mathrm{C}$ until analysis. Before analysis, all the glasswares were cleansed with 1:3 nitric acid and distilled water solution followed by twice with double distilled water and finally rinsed with corresponding water sample. All the reagents used were from Merck, Germany, and were of analytical grade quality. Highly purified water prepared by a Millipore water purification system were used for the experimentation. Analysis of all samples was completed within 2 days after sampling, except for BOD. The analysis of water quality parameters was carried out following the standard methods prescribed in American Public Health Association (APHA 2012). Some of the parameters viz. $\mathrm{pH}$, Oxidation reduction potential (ORP), turbidity, Total dissolve solid (TDS), Dissolve oxygen (DO), electrical conductivity (EC), salinity were measured on the site itself with the help of a multi-parameter water quality analyzer (Model: Horiba $\mathrm{U} 52 \mathrm{G})$. Furthermore, DO, $\mathrm{P}^{\mathrm{H}}$ and EC were also measured in the laboratory using Azide Modification of Winkler Method, Systronics $\mathrm{P}^{\mathrm{H}}$ meter (Model 361) and Systronics Conductivity meter (Model 308), respectively. Chloride was measured using the Argentometric method. Fluoride was measured using 2-(parasulfophenylazo)1,8-dihydroxy-3,6-naphthalene-disulfonate(SPADNS) method. Nitrate was analyzed by Orion ${ }^{\mathrm{TM}}$ Ion selective electrode method. Total hardness was measured by titration with Ethylenediamine tetraacetic acid (EDTA) using Erichrome black-T indicator. Gravimetric method was used to determine Total suspended solid (TSS) and TDS. Acidity and alkalinity were measured by Titration method. Sodium and Potassium were determined with the help of
Systronics Flame photometer (Model-128). Silica was measured by Molybdosilicate method using Ultra-Violet and Visible (UV-VIS) double-beam Spectrophotometer (Model: Electronics India 2375). Sulfate was measured using Turbidimetric Method. Ammonia-Nitrogen was measured using Phenate method for fresh water sample. Ammonia-Nitrogen for wastewater sample was estimated by distillation and followed by titration with $0.02 \mathrm{~N}$ sulfuric acid. Cyanide was measured by Silver nitrate titration method. Oil and grease were determined by extraction and gravimetric method. The results were cross-checked with National Institute of Standard Technology (NIST) certified oil and grease standards. BOD was measured by Bioassay test. The samples collected from fresh water for BOD were collected in $300 \mathrm{~mL}$ BOD bottles. Whereas, the samples collected from the wastewater were diluted with aerated water, added a known volume of micronutrients, and collected in $300 \mathrm{~mL}$ BOD bottles. The time zero samples were immediately fixed with Winkler's reagents for the measurement of control. Another set of samples were maintained at $27{ }^{\circ} \mathrm{C}$ temperature in the BOD incubator for $72 \mathrm{~h}$ before final DO analysis. The change in DO concentrations between first day and final day was measured as BOD. COD analysis was performed by open reflux method and cross-checked with NIST certified COD standards. Phenol analysis was performed by distillation and spectrophotometric method. Heavy metals such as Calcium $\left(\mathrm{Ca}^{2+}\right)$, Magnesium $\left(\mathrm{Mg}^{2+}\right)$, Manganese $(\mathrm{Mn})$, Iron ( $\left.\mathrm{Fe}\right)$, Zinc ( $\mathrm{Zn})$, Copper (Cu), Cadmium (Cd), Lead (Pb), Cobalt (Co), Selenium (Se), Arsenic (As), Mercury (Hg), Chromium (Cr), Manganese (Mn) and Aluminum (Al) were analyzed using an atomic absorption spectrophotometer (PerkinElmer AAnalyst 200). 


\section{Results of the experimental investigation}

The results derived by the above methods are presented in Table 3 along with their descriptive statistics.

The results are subjected to One-Way ANOVA, Correlation Analysis and Principal Component Analysis.

\section{One-Way ANOVA}

The results of one-way ANOVA revealed significant seasonal variation $(p<0.05)$ in the hydro-chemical parameters viz. TSS, Turbidity, Redox Potential, Acidity, Total Hardness, Bicarbonate Alkalinity, Chloride, Sulfate, Nitrate, Sodium, Calcium, Magnesium, Iron, Cadmium, Manganese, Chromium and Magnesium during the entire sampling period. Whereas, no significant seasonal variation $(p>0.05)$ was showed in hydro-chemical parameters such as $\mathrm{pH}, \mathrm{EC}$, TDS, DO, BOD, Residual chlorine, COD, Oil and grease, Fluoride, Potassium, Zinc, Copper, Selenium, Nickel, Aluminum, Boron, Silica, Temperature, Salinity, Cyanide and Phenol.

\section{Correlation analysis}

In this study, the correlation among various parameters had been established using Pearson ' $r$ ' correlation coefficient at 95\% confidence interval level. In premonsoon, strong negative correlation was found between $\mathrm{pH}$ with Zinc and Copper. TDS exhibited Strong positive correlation with chloride, calcium, magnesium and moderate positive correlation with iron. EC showed strong positive correlation with copper and nickel. BOD exhibited strong negative correlation with DO. Chloride displayed strong and moderate positive correlation with calcium and magnesium. Calcium showed strong and moderate positive correlation with magnesium and iron. Magnesium exhibited moderate positive correlation with Iron, selenium and arsenic. Zinc was having high positive correlation with copper and silica. In monsoon, strong negative correlation was found between $\mathrm{pH}$-zinc and $\mathrm{pH}$-nickel. EC exhibited moderate positive correlation with TDS. TDS exhibited moderate positive correlation with potassium, magnesium, zinc, copper, cadmium and nickel. BOD exhibited strong negative correlation with DO. Nitrate displayed positive correlation with calcium and magnesium. Calcium was having moderate positive correlation with magnesium. Zinc showed moderate positive correlation with copper and cadmium. Cadmium and selenium exhibited moderate positive correlation with nickel.

\section{Principal component analysis}

Principal component analysis (PCA) is a significant statistical technique that was used to assess the interrelations between the water quality parameters in Ib valley coalfield. PCA was performed by considering the Rotated Varimax variables with Kaiser normalization on all the water quality parameters (Table 4). On the basis of Eigen values $>1.0$, seven factors were extracted with the cumulative loadings showing a total variability of $89.88 \%$. Factor 1 with eigen value 10.08 accounted for $33.59 \%$ of the total variance. Factor 1 showed strong positive loadings for TDS, residual chlorine, bicarbonate alkalinity, chloride, calcium, magnesium, iron and cadmium and strong negative loadings for manganese and aluminum. Factor 2 with eigen value 5.07 accounted for $16.88 \%$ of the total variance. Factor 2 showed strong positive loadings for EC, redox potential, acidity, copper, silica, salinity and strong negative loading for $\mathrm{pH}$, TSS and Total hardness. Factor 3 with eigen value 3.91 accounted for $13.04 \%$ of the total variance. Factor 3 showed strong positive loadings for BOD, COD and strong negative loading for DO and aluminum. Factor 4 with eigen value 3.13 accounted for $10.45 \%$ of the total variance. Factor 4 showed strong positive loadings for acidity, nitrate, sodium and selenium. Factor 5 with eigen value 1.96 accounted for $6.54 \%$ of the total variance. Factor 5 showed strong positive loadings for TSS, sulfate and temperature. Factor 6 with eigen value 1.54 accounted for $5.15 \%$ of the total variance. Factor 6 showed strong positive loadings for turbidity and potassium. Factor 7 with eigen value 1.27 accounted for $4.24 \%$ of the total variance. Factor 7 exhibited moderate positive loadings for iron and strong negative loading for fluoride.

\section{Data validation}

The analytical precision for the measurement of ions was determined by calculating Charge-Balance Error (CBE). $\mathrm{CBE}$ is defined as the fractional difference between the total cations and total anions(Edmond et al. 1995)

$\mathrm{CBE}=\frac{\sum \text { Cation }-\mid \sum \text { Anion } \mid}{\sum \text { Cation }+\mid \sum \text { Anion } \mid} \times 100$

The CBE can be positive or negative. A positive CBE shows that the water has a higher grouping of cations than anions. On the other hand, a negative CBE demonstrates that anions are more. CBE less than $\pm 5 \%$ are considered acceptable (Huh et al. 1998). The CBE for all the water samples during premonsoon (Fig. 6) and monsoon season (Fig. 7) were found to be less than $\pm 5 \%$, indicating the acceptability of the results. 
Table 3 Descriptive statistics for concentrations of chemical constituents in premonsoon and postmonsoon samples

\begin{tabular}{|c|c|c|c|c|c|}
\hline Parameters & $\begin{array}{l}\text { Premonsoon (Minimum- } \\
\text { Maximum, Average } \pm \text { SD) }\end{array}$ & $\begin{array}{l}\text { Monsoon (Minimum- } \\
\text { Maximum, Average } \pm \text { SD) }\end{array}$ & BIS (2012) & WHO (2011) & MoEF \&CC (2015) \\
\hline $\mathrm{pH}$ & $3.77-7.64(6.43 \pm 0.94)$ & $3.05-7.85(6.78 \pm 1.12)$ & 6.5 to 8.5 & NA & 6.5 to 8.5 \\
\hline $\mathrm{EC}(\mu \mathrm{S} / \mathrm{cm})$ & $\begin{array}{l}58-1580 \\
\quad(430.82 \pm 370.38)\end{array}$ & $\begin{array}{l}32-2120 \\
\quad(406.62 \pm 472.94)\end{array}$ & NA & NA & NA \\
\hline TDS (mg/L) & $291-345(316.55 \pm 13.3)$ & $210-505(300.53 \pm 58.8)$ & 500 & NA & NA \\
\hline TSS (mg/L) & $6-22.99(13.64 \pm 4.57)$ & $\begin{array}{l}21.97-1304.54 \\
(353.12 \pm 264.33)\end{array}$ & NA & NA & $<10$ \\
\hline Turbidity (NTU) & $1.2-14(5.7 \pm 3.44)$ & $\begin{array}{l}0.8-1000 \\
\quad(188.03 \pm 274.69)\end{array}$ & 1 & NA & NA \\
\hline DO (mg/L) & $0.19-6.95(3.08 \pm 1.99)$ & $0.2-6(3.1 \pm 2)$ & NA & NA & $\begin{array}{l}6 \mathrm{mg} / \mathrm{l} \text { or more for drinking } \\
\text { water (Class A) } \\
5 \mathrm{mg} / \mathrm{l} \text { or more for bathing } \\
\text { water (Class B) }\end{array}$ \\
\hline BOD (mg/L) & $10.1-73(33.74 \pm 20.83)$ & $3.6-67.6(25.9 \pm 22.1)$ & NA & NA & $\begin{array}{l}2 \mathrm{mg} / \mathrm{l} \text { or less for drinking } \\
\text { water (Class A) } \\
3 \mathrm{mg} / \mathrm{l} \text { or less for bathing } \\
\text { water (Class B) }\end{array}$ \\
\hline Redox Potential (mV) & $110-379(193.82 \pm 56)$ & $181-384(315.59 \pm 51)$ & NA & NA & NA \\
\hline Acidity (mg/L) & $4-15(8.48 \pm 2.87)$ & $3-146(31.12 \pm 31.43)$ & NA & NA & NA \\
\hline Total Hardness (mg/L) & $60-133(102.79 \pm 18.17)$ & $63-130(93.82 \pm 16.85)$ & 300 & NA & NA \\
\hline Residual chlorine (mg/L) & $\mathrm{BDL}-0.26(0.1 \pm 0.07)$ & $\mathrm{BDL}-0.26(0.09 \pm 0.08)$ & 0.2 & NA & NA \\
\hline COD (mg/L) & $\begin{array}{l}25.4-168.7 \\
\quad(78.14 \pm 52.44)\end{array}$ & $\begin{array}{l}19.87-141.19 \\
(63.56 \pm 49.61)\end{array}$ & NA & NA & $<10$ \\
\hline Oil and grease $(\mathrm{mg} / \mathrm{L})$ & BDL-3.4 $(1.59 \pm 0.98)$ & $0.18-4.3(1.62 \pm 1.12)$ & 10 & NA & NA \\
\hline $\begin{array}{l}\text { Bicarbonate Alkalinity } \\
(\mathrm{mg} / \mathrm{L})\end{array}$ & $30-80.3(61.01 \pm 13.71)$ & $13.49-72.6(39.54 \pm 15.6)$ & 200 & NA & NA \\
\hline Chloride (mg/L) & $12-42.8(29.06 \pm 9.79)$ & $\begin{array}{l}17.66-33.11 \\
(24.71 \pm 4.75)\end{array}$ & 250 & $200-300$ & NA \\
\hline Fluoride (mg/L) & $0.1-0.54(0.26 \pm 0.13)$ & $0.007-0.79(0.4 \pm 0.22)$ & 1 & 1.5 & NA \\
\hline Sulfate $(\mathrm{mg} / \mathrm{L})$ & $\begin{array}{c}10.82-177.97 \\
(91.56 \pm 44.08)\end{array}$ & $\begin{array}{l}52.11-493.23 \\
\quad(155.47 \pm 87.15)\end{array}$ & 200 & NA & NA \\
\hline Nitrate (mg/L) & $8.9-22.2(15.71 \pm 3.11)$ & $3.7-19.9(12.49 \pm 3.71)$ & 45 & 50 & NA \\
\hline Sodium (mg/L) & $5-29(14.4 \pm 6.48)$ & $6.96-47.45(19.41 \pm 9.38)$ & NA & NA & NA \\
\hline Potassium (mg/L) & $4.83-35.67(18.35 \pm 7.82)$ & $5.5-45.32(18.82 \pm 11.08)$ & NA & NA & NA \\
\hline Calcium (mg/L) & $15.1-37.8(24.02 \pm 5.64)$ & $14.3-58.43(30.73 \pm 9.4)$ & 75 & NA & NA \\
\hline Magnesium (mg/L) & $18.8-46.9(31.81 \pm 6.93)$ & $\begin{array}{l}15.31-47.61 \\
(28.35 \pm 7.13)\end{array}$ & 30 & NA & NA \\
\hline Iron $(\mathrm{mg} / \mathrm{L})$ & $\begin{array}{l}\text { BDL }-0.17 \\
\quad(0.0455 \pm 0.0401)\end{array}$ & $\begin{array}{l}0.01-1.87 \\
\quad(0.5221 \pm 0.6581)\end{array}$ & 0.3 & NA & NA \\
\hline Zinc (mg/L) & $\begin{array}{l}\text { BDL }-0.32 \\
(0.0355 \pm 0.0864)\end{array}$ & $\begin{array}{l}\text { BDL }-0.84 \\
\quad(0.0904 \pm 0.1926)\end{array}$ & 5 & NA & NA \\
\hline Copper (mg/L) & $\begin{array}{l}0.005-0.243 \\
\quad(0.0438 \pm 0.0668)\end{array}$ & $\begin{array}{l}\text { BDL }-1.21 \\
\quad(0.044 \pm 0.2065)\end{array}$ & 0.05 & 2.0 & NA \\
\hline Cadmium (mg/L) & $\begin{array}{l}0.001-0.01 \\
\quad(0.0049 \pm 0.0016)\end{array}$ & $\begin{array}{l}\text { BDL }-0.009 \\
(0.0033 \pm 0.0023)\end{array}$ & 0.003 & 0.003 & NA \\
\hline Selenium (mg/L) & $\begin{array}{l}0.027-0.099 \\
\quad(0.0612 \pm 0.0185)\end{array}$ & $\begin{array}{l}0.011-0.579 \\
\quad(0.0596 \pm 0.0933)\end{array}$ & 0.01 & 0.01 & NA \\
\hline Arsenic (mg/L) & $\begin{array}{l}\text { BDL }-0.018 \\
\quad(0.0023 \pm 0.005)\end{array}$ & $\begin{array}{l}\text { BDL }-0.015 \\
\quad(0.0021 \pm 0.004)\end{array}$ & 0.01 & 0.01 & NA \\
\hline Mercury (mg/L) & $\mathrm{BDL}-\mathrm{BDL}(\mathrm{NA} \pm \mathrm{NA})$ & $\mathrm{BDL}-\mathrm{BDL}(\mathrm{NA} \pm \mathrm{NA})$ & 0.001 & 0.006 & NA \\
\hline Chromium (mg/L) & $\begin{array}{l}\text { BDL }-0.01 \\
\quad(0.0009 \pm 0.0023)\end{array}$ & $\begin{array}{l}\text { BDL }-0.032 \\
(0.0025 \pm 0.0077)\end{array}$ & 0.05 & 0.05 & NA \\
\hline Nickel (mg/L) & $\begin{array}{l}\text { BDL-0.346 } \\
\quad(0.0545 \pm 0.0993)\end{array}$ & $\begin{array}{l}\text { BDL-0.71 } \\
\quad(0.0938 \pm 0.179)\end{array}$ & 0.02 & 0.07 & NA \\
\hline
\end{tabular}


Table 3 (continued)

\begin{tabular}{|c|c|c|c|c|c|}
\hline Parameters & $\begin{array}{l}\text { Premonsoon (Minimum- } \\
\text { Maximum, Average } \pm \text { SD) }\end{array}$ & $\begin{array}{l}\text { Monsoon (Minimum- } \\
\text { Maximum, Average } \pm \text { SD) }\end{array}$ & BIS (2012) & WHO (2011) & MoEF \&CC (2015) \\
\hline Lead (mg/L) & $\mathrm{BDL}-\mathrm{BDL}(\mathrm{NA} \pm \mathrm{NA})$ & $\begin{array}{l}\text { BDL }-0.013 \\
\quad(0.0004 \pm 0.0022)\end{array}$ & 0.01 & 0.01 & NA \\
\hline Manganese (mg/L) & $0.06-0.01(0.03 \pm 0.01)$ & $0.06-0.01(0.03 \pm 0.01)$ & 0.1 & 0.4 & NA \\
\hline Aluminum (mg/L) & $0.08-0.84(0.37 \pm 0.17)$ & $0.08-0.84(0.37 \pm 0.17)$ & 0.03 & NA & NA \\
\hline Boron (mg/L) & $\begin{array}{l}\text { BDL-1.671 } \\
\quad(0.1068 \pm 0.3563)\end{array}$ & $\begin{array}{l}\text { BDL }-0.037 \\
(0.0054 \pm 0.0104)\end{array}$ & 0.5 & 0.5 & NA \\
\hline Silica $(\mathrm{mg} / \mathrm{L})$ & $0.829-16.23(4.38 \pm 3.53)$ & $0.56-15.46(3.79 \pm 3.2)$ & NA & NA & NA \\
\hline Temperature $\left({ }^{\circ} \mathrm{C}\right)$ & $30.9-32.4(31.7 \pm 0.49)$ & $\begin{array}{l}31.17-33.86 \\
\quad(31.65 \pm 0.58)\end{array}$ & NA & NA & NA \\
\hline Salinity (ppt) & $\begin{array}{l}\mathrm{BDL}-0.8 \\
\quad(0.2061 \pm 0.1983)\end{array}$ & $\begin{array}{l}\text { BDL-1.1 } \\
\quad(0.2118 \pm 0.2306)\end{array}$ & NA & NA & NA \\
\hline Cyanide (mg/L) & $\begin{array}{l}\text { BDL }-0.02 \\
(0.0016 \pm 0.0042)\end{array}$ & $\begin{array}{l}\text { BDL }-0.017 \\
\quad(0.0012 \pm 0.0037)\end{array}$ & 0.05 & 0.07 & NA \\
\hline Phenol (mg/L) & $\begin{array}{l}\text { BDL }-0.006 \\
(0.0004 \pm 0.0012)\end{array}$ & $\begin{array}{l}\text { BDL }-0.003 \\
\quad(0.0002 \pm 0.0006)\end{array}$ & 0.001 & NA & NA \\
\hline $\mathrm{Na} \%$ & $12.1-33.22(22.6 \pm 5.68)$ & $\begin{array}{l}12.37-45.19 \\
(25.09 \pm 7.89)\end{array}$ & Refer Table 9 & & \\
\hline SAR & $0.35-0.9(0.57 \pm 0.14)$ & $0.37-1.11(0.65 \pm 0.16)$ & & & \\
\hline RSC & $-3.54--0.82(-2.02 \pm 0.7)$ & $\begin{array}{l}-6.43--0.86 \\
(-2.86 \pm 1.13)\end{array}$ & & & \\
\hline MH & $\begin{array}{l}49.79-75.89 \\
(68.45 \pm 5.19)\end{array}$ & $\begin{array}{l}46.31-75.36 \\
\quad(60.48 \pm 7.11)\end{array}$ & & & \\
\hline
\end{tabular}

\section{Index approach}

Quality indices are suitable for getting a composite impact of all parameters into pollution. Additionally, it makes the evaluations into a reproducible form and compiles all the pollution parameters into some easy approach (Balakrishnan and Ramu 2016). The water quality index (WQI), heavy metal pollution index (HPI), Degree of contamination ( $\mathrm{Cd}$ or $\mathrm{C} \mathrm{deg}$ ) and heavy metal evaluation index (HEI) are some of the indices that represent the quality of water at any locations, and these have been discussed here.

\section{Water quality index}

Figuring of water quality index is to transform complex water quality data into information that is understandable and usable by the general public. Water quality index is one of the most commonly used tools to ascertain water quality. There are a lot of water quality indices used nowadays. The most reliable among them is weighted arithmetic water quality index (WA-WQI). The calculation of WQI was performed by using the following equation (Yogendra and Puttaiah 2008):
$\mathrm{WQI}=\frac{\sum_{i=1}^{n} Q_{i} W_{i}}{\sum_{i=1}^{n} W_{i}}$

The Quality rating scale $Q_{i}$ is estimated by the expression:

$Q_{i}=100\left[\frac{\left(V_{i}-V_{0}\right)}{\left(S_{i}-V_{0}\right)}\right]$

where, $V_{i}$ is calculated concentration of $i$ th parameter in the sample water, $V_{0}$ is the ideal value of this parameter in pure water $V_{0}=0$ (except $\mathrm{pH}=7.0$ and $\mathrm{DO}=14.6 \mathrm{mg} / \mathrm{L}$ ), $S_{i}$ is recommended standard value (Bureau of Indian Standards, 2012) of $i$ th parameter, is the unit weight.

$W_{i}=\frac{K}{S_{i}}$

where, $K=$ proportionality constant and is calculated as

$K=\frac{1}{\sum\left(\frac{1}{S_{i}}\right)}$

The quality index of all the samples was determined using the above relationship, and the results are presented in Table 5. 
Table 4 Rotated varimax principal component analysis of the water quality parameter

\begin{tabular}{|c|c|c|c|c|c|c|c|}
\hline & \multicolumn{7}{|c|}{ Rotated Component Matrix ${ }^{a}$} \\
\hline & \multicolumn{7}{|c|}{ Component loading } \\
\hline & Factor 1 & Factor 2 & Factor 3 & Factor 4 & Factor 5 & Factor 6 & Factor 7 \\
\hline $\mathrm{pH}$ & 0.23 & -0.86 & -0.06 & -0.18 & -0.08 & 0.15 & -0.05 \\
\hline $\mathrm{EC}(\mu \mathrm{S} / \mathrm{cm})$ & 0.38 & 0.88 & 0.01 & 0.05 & -0.06 & 0.03 & -0.05 \\
\hline TSS (mg/L) & 0.17 & -0.51 & -0.19 & 0.15 & 0.60 & 0.04 & -0.31 \\
\hline TDS (mg/L) & 0.87 & 0.20 & 0.25 & 0.03 & 0.32 & 0.03 & -0.02 \\
\hline Turbidity (NTU) & 0.06 & -0.34 & 0.02 & -0.28 & -0.11 & 0.69 & 0.04 \\
\hline $\mathrm{DO}(\mathrm{mg} / \mathrm{L})$ & -0.02 & -0.19 & -0.96 & -0.08 & -0.17 & 0.00 & 0.01 \\
\hline BOD (mg/L) & 0.10 & -0.01 & 0.97 & 0.11 & 0.00 & 0.03 & -0.06 \\
\hline Redox Potential (mV) & 0.26 & 0.88 & 0.06 & -0.15 & 0.17 & 0.12 & 0.16 \\
\hline Acidity (mg/L) & -0.03 & 0.58 & -0.21 & 0.69 & 0.02 & -0.14 & 0.05 \\
\hline Total Hardness (mg/L) & -0.03 & -0.63 & -0.27 & 0.25 & 0.44 & 0.29 & -0.05 \\
\hline Residual chlorine (mg/L) & 0.85 & 0.13 & -0.07 & -0.21 & -0.11 & -0.02 & 0.10 \\
\hline $\mathrm{COD}(\mathrm{mg} / \mathrm{L})$ & 0.19 & 0.14 & 0.95 & 0.07 & -0.05 & 0.02 & 0.11 \\
\hline Bicarbonate Alkalinity (mg/L) & 0.76 & 0.13 & 0.11 & 0.36 & 0.01 & 0.32 & -0.25 \\
\hline Chloride (mg/L) & 0.89 & 0.30 & 0.13 & -0.03 & 0.28 & 0.05 & -0.06 \\
\hline Fluoride (mg/L) & 0.08 & -0.41 & -0.03 & 0.05 & -0.07 & -0.25 & -0.77 \\
\hline Sulfate $(\mathrm{mg} / \mathrm{L})$ & 0.33 & -0.11 & 0.31 & -0.07 & 0.72 & 0.00 & 0.19 \\
\hline Nitrate (mg/L) & 0.21 & 0.01 & 0.15 & 0.84 & -0.29 & 0.14 & -0.10 \\
\hline Sodium (mg/L) & -0.18 & -0.15 & 0.12 & 0.82 & 0.25 & -0.26 & -0.29 \\
\hline Potassium (mg/L) & 0.21 & 0.28 & 0.03 & -0.09 & 0.29 & 0.82 & 0.19 \\
\hline Calcium (mg/L) & 0.94 & 0.20 & 0.08 & 0.06 & 0.20 & 0.06 & -0.03 \\
\hline Magnesium (mg/L) & 0.72 & 0.08 & 0.32 & 0.30 & 0.39 & 0.02 & 0.03 \\
\hline $\operatorname{Iron}(\mathrm{mg} / \mathrm{L})$ & 0.59 & -0.05 & 0.10 & 0.47 & -0.22 & -0.43 & 0.37 \\
\hline Copper (mg/L) & 0.28 & 0.92 & 0.07 & 0.05 & -0.04 & 0.13 & 0.11 \\
\hline Cadmium (mg/L) & 0.73 & 0.02 & 0.07 & 0.17 & 0.06 & -0.14 & 0.44 \\
\hline Selenium (mg/L) & 0.16 & -0.04 & 0.08 & 0.82 & 0.11 & -0.29 & 0.34 \\
\hline Manganese (mg/L) & -0.77 & -0.20 & -0.10 & -0.01 & 0.24 & -0.39 & 0.21 \\
\hline Aluminum (mg/L) & -0.58 & 0.00 & -0.66 & 0.44 & 0.01 & 0.03 & -0.11 \\
\hline Silica $(\mathrm{mg} / \mathrm{L})$ & 0.18 & 0.94 & 0.10 & -0.07 & -0.11 & 0.07 & 0.12 \\
\hline Temperature $\left({ }^{\circ} \mathrm{C}\right)$ & 0.59 & 0.30 & -0.03 & -0.15 & 0.58 & 0.33 & 0.10 \\
\hline Salinity (ppt) & 0.39 & 0.85 & 0.06 & 0.08 & -0.10 & -0.01 & -0.02 \\
\hline Eigen value & 10.08 & 5.07 & 3.91 & 3.13 & 1.96 & 1.54 & 1.27 \\
\hline$\%$ of variance & 33.59 & 16.88 & 13.04 & 10.45 & 6.54 & 5.15 & 4.24 \\
\hline$\%$ of cumulative variance & 33.59 & 50.47 & 63.51 & 73.96 & 80.49 & 85.64 & 89.88 \\
\hline
\end{tabular}

Extraction Method: Principal Component Analysis

Rotation Method: Varimax with Kaiser Normalization

${ }^{\text {a }}$ Rotation converged in 12 iterations

\section{Heavy metal pollution index (HPI)}

HPI is a rating technique that represents the total quality of water with respect to their heavy metals content. The HPI model is calculated (Tiwari et al. 2016) as:

HPI $=\frac{\sum_{i=1}^{n} W_{i} Q_{i}}{\sum_{i=1}^{n} W_{i}}$ where $W_{i}=\frac{1}{S_{i}}$ (Prasad and Bose 2001). $Q_{i}$ is the sub-index of the $i$ th parameter, $W_{i}$ is the unit weight of the $i$ th parameter and $\mathrm{n}$ is the total number of parameters taken into consideration. The sub-index $Q_{i}$ of the parameter is determined by the following equation

$Q_{i}=\sum_{i=1}^{n} \frac{M_{i}(-) L_{i}}{\left(S_{i}-L_{i}\right)}$ 


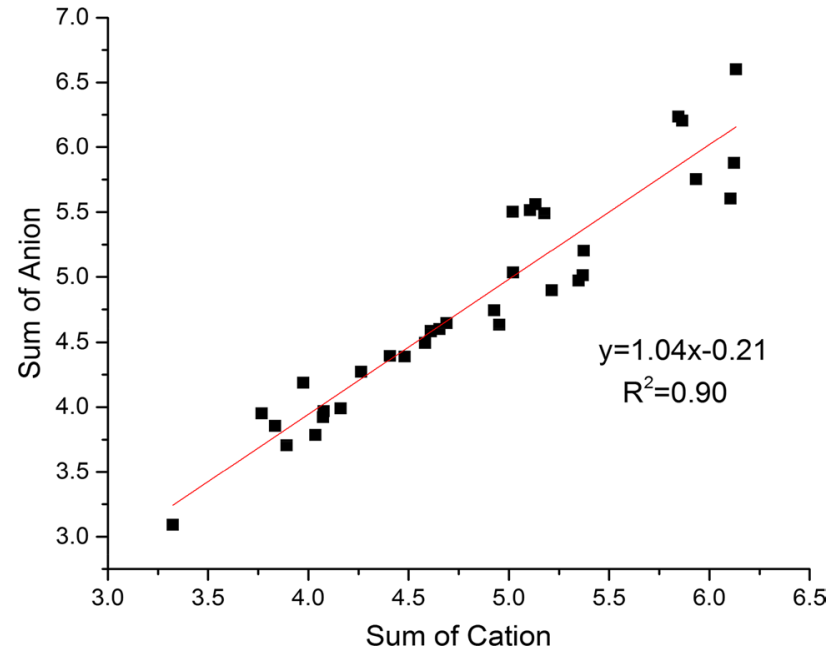

Fig. 6 CBE plot of water samples for premonsoon season

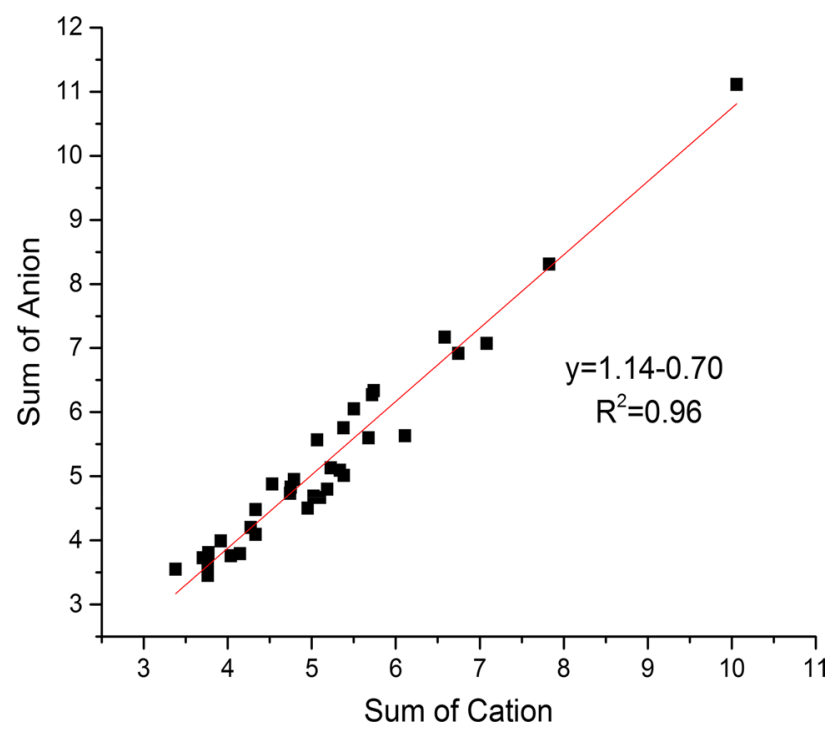

Fig. 7 CBE plot of water samples for monsoon season

where $M_{i}$ the estimated value of heavy metal of ith parameter is, $L_{i}$ is the ideal value of the $i$ th parameter and $\mathrm{Si}$ is the prescribed standard value of the $i$ th parameter in $\mathrm{ppb}$. The sign (-) shows the numerical difference of the two values, ignoring the algebraic sign; that is the absolute value.

Usually, the critical pollution index of HPI value for drinking water is 100 . Any water having HPI $>100$ is not suitable for drinking (Prasad and Bose 2001). The heavy metal pollution indices for all the samples collected during premonsoon and monsoon period are also presented in Table 5.

\section{Degree of contamination (Cd or C deg)}

The degree of contamination ( $\mathrm{Cd}$ or $\mathrm{C} \mathrm{deg}$ ) of metal explains the magnitude of contamination of metal. It describes the collective effect of heavy or trace metals, which is detrimental to drinking water (Loska et al. 2004). The Cd value is categorized into three classes: low $(\mathrm{Cd}<1)$, medium $(1<\mathrm{Cd}<3)$ and high $(\mathrm{Cd}>3)$. The degree of contamination is measured as:

$C_{d}=\sum_{i=1}^{n} C_{f}$

$C_{f}=\frac{C_{A i}}{C_{N i}}-1$

where, $C_{\mathrm{d}}$ is the degree of contamination, $C_{\mathrm{f}}$ is the contamination factor, $C_{\mathrm{Ai}}$ is the analytical value of the metal, $C_{\mathrm{Ni}}$ is the upper permissible limit of metal of ith parameter.

The degree of contamination along with mean and percentage deviation of all the water samples is presented in Table 6.

\section{Heavy metal evaluation index (HEI)}

Heavy metal evaluation index (HEI) explains overall water quality of a specific area in regard to heavy metals. The HEI is measured by the following equation (Edet and Offiong 2002).

$\mathrm{HEI}=\sum_{i=1}^{n} \frac{H_{c}}{H_{\mathrm{mac}}}$

where, $H_{\mathrm{c}}$ is the analytical concentration of the $i$ th parameter and $H_{\text {mac }}$ is the maximum permissible concentration of the $i$ th parameter.

The HEI along with mean and percentage deviation for all the water samples is also presented in Table 6.

The Water Quality Rating for the WA-WQI method is presented in Table 7. When compared with the WQI values for all the water samples (Table 5), it could be seen that in premonsoon, $48.48 \%$ samples were good, $39.39 \%$ poor, and $12.12 \%$ very poor. Similarly, in monsoon, $41.18 \%$ water samples were good, $35.29 \%$ poor, $17.65 \%$ very poor, and $5.88 \%$ unfit for drinking. In general, it was found that the water quality of sump water is better compared to other samples. This may be due to the fact that coal is a natural filter and adsorbs a variety of pollutants.

The mean-based reclassification method as proposed by Edet and Offiong (2002) incorporating HPI, Cd and HEI is presented in Table 8 . The samples for which the values of HPI, Cd, and HEI fall below the mean value or have negative percentage deviation, indicates comparatively healthier water quality (Prasad and Bose 2001; Edet and Offiong 2002). The water quality is assigned as "low" for values 
Table 5 Details of WQI and Mean-based reclassification methods based on HPI of water samples in Premonsoon and Monsoon season

\begin{tabular}{|c|c|c|c|c|c|c|c|c|}
\hline \multirow[t]{2}{*}{ Sample No } & \multirow{2}{*}{$\begin{array}{l}\text { Premonsoon } \\
\text { Season } \\
\text { WQI }\end{array}$} & \multirow{2}{*}{$\begin{array}{l}\text { Monsoon Season } \\
\text { WQI }\end{array}$} & \multicolumn{3}{|c|}{ Premonsoon Season } & \multicolumn{3}{|c|}{ Monsoon Season } \\
\hline & & & HPI & Mean deviation & $\%$ deviation & HPI & Mean deviation & $\%$ deviation \\
\hline 1 & 58.91 & 56.33 & 113.03 & 14.22 & 14.39 & 87.28 & -10.20 & 89.54 \\
\hline 2 & 43.66 & 38.30 & 98.43 & -0.38 & -0.38 & 78.99 & -18.49 & 81.03 \\
\hline 3 & 41.63 & 41.25 & 123.54 & 24.73 & 25.03 & 67.46 & -30.02 & 69.20 \\
\hline 4 & 34.03 & 40.90 & 109.04 & 10.23 & 10.36 & 88.74 & -8.74 & 91.03 \\
\hline 5 & 82.18 & 46.98 & 126.39 & 27.58 & 27.91 & 497.38 & 399.90 & 510.24 \\
\hline 6 & 44.22 & 80.93 & 72.35 & -26.46 & -26.78 & 69.16 & -28.32 & 70.95 \\
\hline 7 & 76.08 & 48.82 & 89.20 & -9.61 & -9.73 & 59.86 & -37.62 & 61.40 \\
\hline 8 & 58.35 & 45.91 & 106.81 & 8.00 & 8.09 & 141.18 & 43.70 & 144.82 \\
\hline 9 & 39.98 & 41.47 & 82.38 & -16.43 & -16.63 & 125.21 & 27.73 & 128.45 \\
\hline 10 & 41.65 & 68.44 & 143.63 & 44.82 & 45.36 & 143.74 & 46.26 & 147.46 \\
\hline 11 & 43.99 & 73.06 & 138.90 & 40.09 & 40.57 & 211.30 & 113.82 & 216.77 \\
\hline 12 & 47.03 & 47.82 & 132.04 & 33.23 & 33.63 & 117.80 & 20.32 & 120.85 \\
\hline 13 & 78.98 & 102.69 & 102.48 & 3.67 & 3.71 & 79.00 & -18.48 & 81.04 \\
\hline 14 & 73.13 & 101.25 & 95.08 & -3.73 & -3.77 & 89.01 & -8.47 & 91.31 \\
\hline 15 & 69.29 & 69.23 & 102.48 & 3.67 & 3.71 & 75.39 & -22.09 & 77.34 \\
\hline 16 & 58.03 & 66.71 & 100.52 & 1.71 & 1.73 & 52.96 & -44.52 & 54.33 \\
\hline 17 & 51.54 & 67.81 & 94.82 & -3.99 & -4.04 & 64.75 & -32.73 & 66.43 \\
\hline 18 & 31.35 & 47.08 & 131.61 & 32.80 & 33.20 & 87.09 & -10.39 & 89.34 \\
\hline 19 & 42.92 & 91.34 & 71.36 & -27.45 & -27.78 & 48.47 & -49.01 & 49.72 \\
\hline 20 & 41.46 & 87.38 & 65.28 & -33.53 & -33.93 & 74.17 & -23.31 & 76.09 \\
\hline 21 & 60.61 & 79.86 & 80.35 & -18.46 & -18.68 & 69.81 & -27.67 & 71.62 \\
\hline 22 & 39.09 & 79.72 & 80.71 & -18.10 & -18.32 & 64.54 & -32.94 & 66.20 \\
\hline 23 & 58.58 & 54.30 & 118.00 & 19.19 & 19.42 & 106.64 & 9.16 & 109.40 \\
\hline 24 & 50.01 & 58.02 & 132.54 & 33.73 & 34.13 & 94.79 & -2.69 & 97.24 \\
\hline 25 & 27.65 & 48.46 & 119.70 & 20.89 & 21.14 & 100.87 & 3.39 & 103.48 \\
\hline 26 & 39.00 & 27.88 & 89.05 & -9.76 & -9.88 & 132.15 & 34.67 & 135.57 \\
\hline 27 & 84.08 & 79.40 & 71.09 & -27.72 & -28.05 & 65.30 & -32.18 & 66.98 \\
\hline 28 & 61.85 & 26.35 & 79.66 & -19.15 & -19.38 & 84.34 & -13.14 & 86.52 \\
\hline 29 & 59.96 & 61.46 & 71.90 & -26.91 & -27.24 & 73.65 & -23.83 & 75.56 \\
\hline 30 & 31.08 & 28.66 & 69.91 & -28.90 & -29.24 & 64.82 & -32.66 & 66.50 \\
\hline 31 & 38.34 & 55.72 & 106.02 & 7.21 & 7.30 & 57.24 & -40.24 & 58.72 \\
\hline 32 & 60.26 & 59.28 & 72.63 & -26.18 & -26.50 & 50.89 & -46.59 & 52.21 \\
\hline 33 & 50.25 & 58.73 & 69.72 & -29.09 & -29.44 & 46.63 & -50.85 & 47.83 \\
\hline 34 & Nil & 44.44 & Nil & Nil & Nil & 43.53 & -53.95 & 44.66 \\
\hline MAX & 84.08 & 102.69 & 143.63 & Nil & Nil & 497.38 & Nil & Nil \\
\hline MIN & 27.65 & 22.88 & 65.28 & Nil & Nil & 43.53 & Nil & Nil \\
\hline Mean & 52.10 & 59.44 & 98.81 & Nil & Nil & 97.48 & Nil & Nil \\
\hline SD & 15.36 & 20.27 & 23.40 & Nil & Nil & 78.63 & Nil & Nil \\
\hline
\end{tabular}

less than the mean value, medium for those values which remain between mean and two times of the mean value and, as high for those values which are more than two times of the mean. It could be seen that a total of $48.84 \%$ of the sample were under the mean of HPI in premonsoon and $73.53 \%$ in monsoon. Correspondingly, 54.55\%, 66.67\% samples had $\mathrm{Cd}$ and HPI indices below their mean values in premonsoon and $54.55 \%$ and $61.76 \%$ in monsoon.

\section{Graphical representation of water quality data}

\section{Hydrochemical facies}

Piper trilinear plot was made using Origin Pro 2016 to determine the major cations and anions of analyzed water samples (Figs. 8, 9). The dominant anions were found to be sulfate 


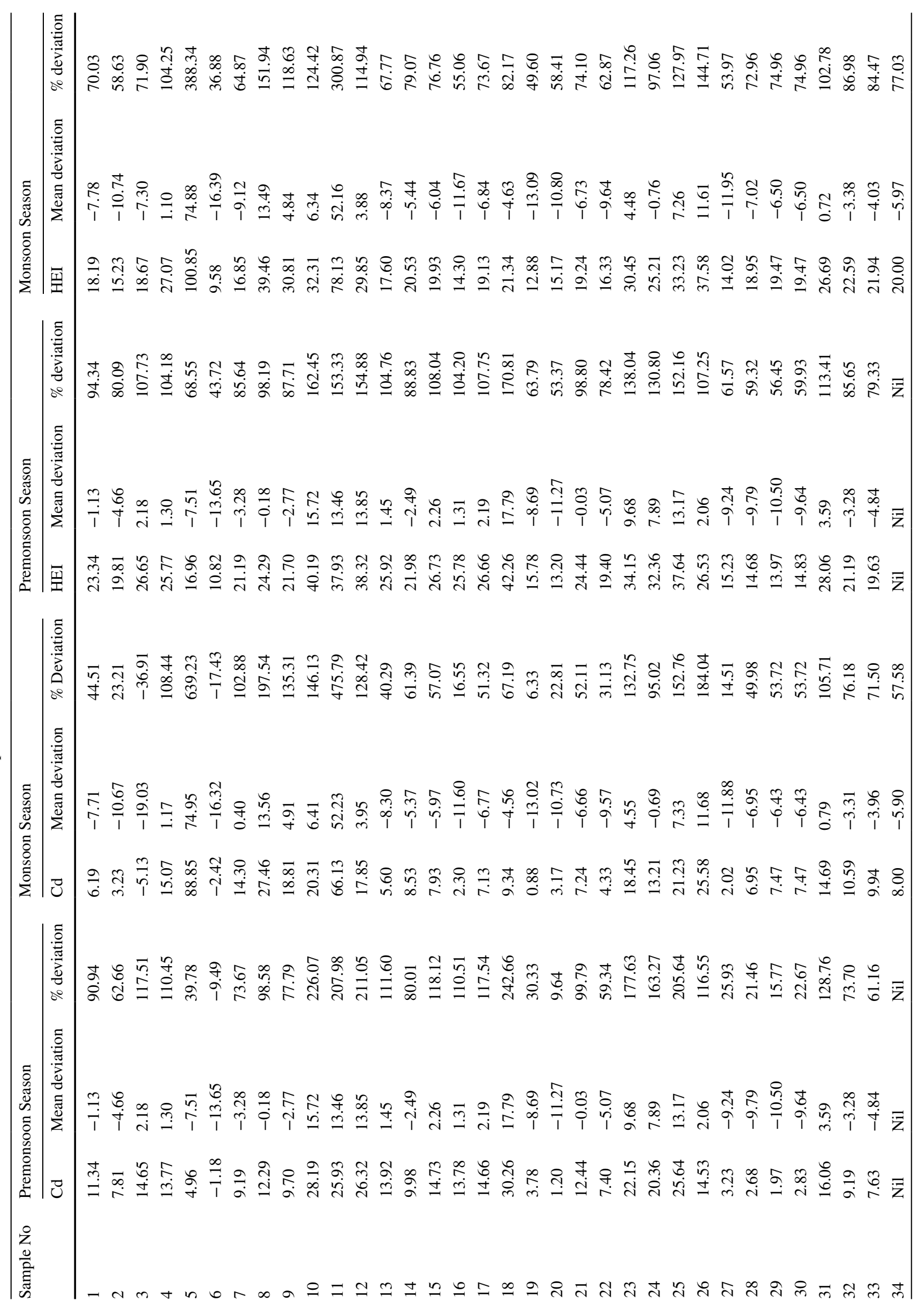


and chloride because of the oxidation of sulfides and disintegration of sandstone and shale. The major cations were calcium and magnesium. These may be produced due to weathering and leaching of carbonate and silicate minerals such as crystalline dolomitic limestone, calcium-magnesium silicate and biotite. The two major hydrogeochemical facies were found to be Calcium-Magnesium-Chloride and Calcium-Magnesium-Sulfate in the study area. The later was predominant in water contaminated areas due to mining activities.

\section{Concentration contour mapping}

Contour mapping is one of the ideal approaches to visualize spatial differences in water quality. The Geographical Information System (GIS)-based analysis of the concentration contour maps of the study area was made using Arc GIS 10.5 software with the kriging interpolation technique. Kriging is a statistical model that uses autocorrelation. In this technique, the distance or direction between the sample points is assumed that reflects a spatial correlation to explain variation in the surface. Kriging usually incorporates statistical analysis of the data, variogram model, creating surface and optionally exploring a variance surface. The concentration contour maps for some of the important parameters and indices viz. $\mathrm{pH}, \mathrm{Fe}, \mathrm{Se}, \mathrm{WQI}, \mathrm{HPI}$ and $\mathrm{MH}$ are presented in Figs. 10, 11, 12, 13, 14 and 15.

\section{Suitability for irrigation}

Most of the opencast and underground mines extend below the water table and hence change the hydraulic gradient. This lead to change in the surface as well as groundwater flow regime which affect their quality and quantity. Due to lack of water in the mining area, the mine discharge water can be utilized for irrigation after a proper scientific investigation. The most important water quality parameters to be considered for irrigation purpose are TDS, EC, Salinity, Percent Sodium (Na \%), Sodium absorption ratio (SAR), Residual Sodium Carbonate (RSC) and Magnesium Hazard (MH) (Mondal et al. 2012). These parameters were determined for all the collected water samples, and the summary statistics of the results are presented in Table 9.

$$
\begin{aligned}
& \mathrm{SAR}=\frac{\text { Sodium }}{\sqrt{\left(\frac{\text { Calcium+Magnesium }}{2}\right)}} \\
& \mathrm{Na} \%=\frac{\text { Sodium }+ \text { Potassium }}{(\text { Calcium }+ \text { Magnesium }+ \text { Sodium }+ \text { Potassium })} \times 100
\end{aligned}
$$


Table 7 Water quality rating as per weight arithmetic water quality index method (Yogendra and Puttaiah 2008)

\begin{tabular}{|c|c|c|c|c|c|c|}
\hline \multirow[t]{2}{*}{ WQI Value } & \multirow[t]{2}{*}{ Water Quality Rating } & \multirow[t]{2}{*}{ Grade } & \multicolumn{2}{|l|}{ Premonsoon } & \multicolumn{2}{|l|}{ Monsoon } \\
\hline & & & No. of Sample & $\%$ of Sample & No. of Sample & $\%$ of Sample \\
\hline $0-25$ & Excellent & A & 0 & 0 & 0 & 0 \\
\hline $26-50$ & Good & B & 16 & 48.48 & 14 & 41.18 \\
\hline $51-75$ & Poor & $\mathrm{C}$ & 13 & 39.39 & 12 & 35.29 \\
\hline $76-100$ & Very Poor & D & 4 & 12.12 & 6 & 17.65 \\
\hline$>100$ & Unfit for drinking & $\mathrm{E}$ & 0 & 0 & 2 & 5.88 \\
\hline
\end{tabular}

\begin{tabular}{|c|c|c|c|c|c|}
\hline Season & Index method & Category & Degree of pollution & $\begin{array}{l}\text { No. of } \\
\text { samples }\end{array}$ & $\%$ of sample \\
\hline \multirow[t]{9}{*}{ Premonsoon } & \multirow[t]{3}{*}{ HPI } & $<98.81$ & Low & 16 & 48.48 \\
\hline & & $98.81-197.62$ & Medium & 17 & 51.52 \\
\hline & & $>197.62$ & High & 0 & 0 \\
\hline & \multirow[t]{3}{*}{$\mathrm{Cd}$} & $<12.47$ & Low & 18 & 54.55 \\
\hline & & $12.47-24.94$ & Medium & 10 & 30.30 \\
\hline & & $>24.94$ & High & 5 & 15.15 \\
\hline & \multirow[t]{3}{*}{ HEI } & $<24.47$ & Low & 18 & 54.55 \\
\hline & & $24.47-48.94$ & Medium & 15 & 45.45 \\
\hline & & $>48.94$ & High & 0 & 0 \\
\hline \multirow[t]{9}{*}{ Monsoon } & \multirow[t]{3}{*}{ HPI } & $<97.48$ & Low & 25 & 73.53 \\
\hline & & $97.48-194.96$ & Medium & 7 & 20.59 \\
\hline & & $>194.96$ & High & 2 & 5.88 \\
\hline & \multirow[t]{3}{*}{$\mathrm{Cd}$} & $<13.90$ & Low & 21 & 61.76 \\
\hline & & $13.90-27.8$ & Medium & 12 & 35.29 \\
\hline & & $>27.8$ & High & 1 & 2.94 \\
\hline & \multirow[t]{3}{*}{ HEI } & $<25.97$ & Low & 23 & 67.65 \\
\hline & & $25.97-51.94$ & Medium & 9 & 26.47 \\
\hline & & $>51.94$ & High & 2 & 5.88 \\
\hline
\end{tabular}

Table 8 Water quality rating based on mean-based reclassification methods including HPI, Cd, and HEI in Premonsoon and Monsoon season

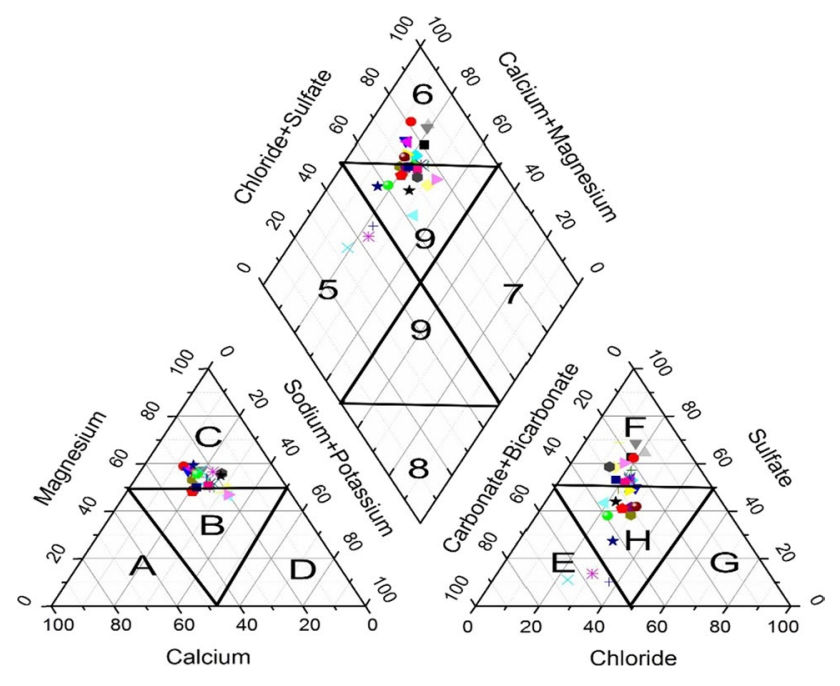

$\mathrm{RSC}=($ Bicarbonate + Carbonate $)-($ Calcium + Magnesium $)$

$\mathrm{PI}=\frac{(\text { Sodium }+\sqrt{\text { Bicarbonate }}) \times 100}{\text { Calcium }+ \text { Magnesium }+ \text { Sodium }}$

$\mathrm{MH}=\left(\frac{\text { Magnesium }}{\text { Calcium }+ \text { Magnesium }}\right) \times 100$

Fig. 8 Piper plot of water samples for premonsoon season

\section{Discussion}

The following important observations were observed from the analysis in both premonsoon and monsoon season: 


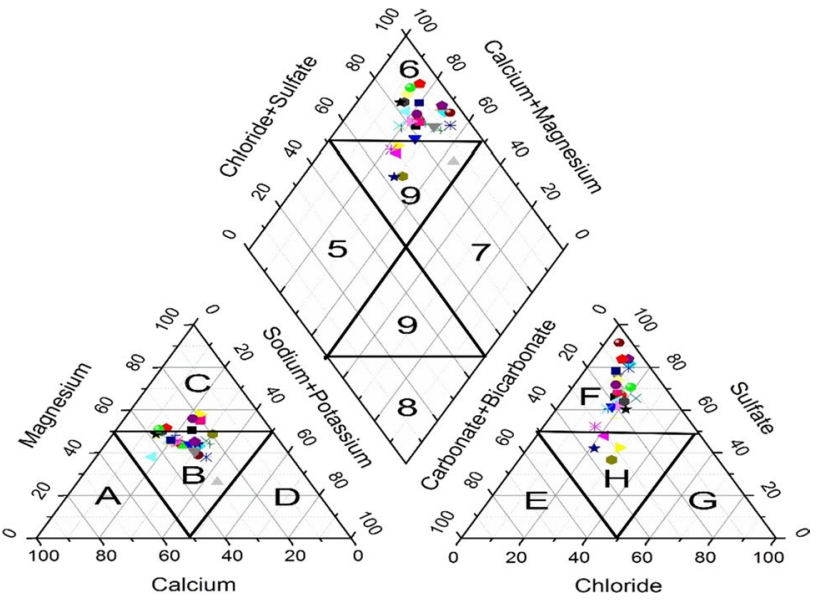

Fig. 9 Piper plot of water samples for monsoon season. The piper diagram can be separated in hydrogeochemical facies. Legend: A: Calcium type; B: No dominant type; C: Magnesium Type; D: Sodium and Potassium type; E: Bicarbonate type; F: Sulfate type; G: Chloride type; $\mathrm{H}$ : No dominant type; 1: Alkaline earths exceed alkalis; 2: Alkalies exceed Alkaline earths; 3: Week acids exceed strong acids; 4: Strong acids exceed week acids; 5: Magnesium Bicarbonate type; 6: Calcium chloride type; 7: Sodium Chloride type; 8: Sodium Bicarbonate type; 9 : Mixed type $(1: 5+9+6,2: 8+9+7,3: 5+9+8$ and $4: 6+9+7)$

\section{pH}

The mine water was acidic to neutral to slightly alkaline in nature. The minimum values of $\mathrm{pH}$ were recorded in Samaleswari OCP railway siding inlet (3.77) during premonsoon and south sump (3.05) in monsoon, making it highly acidic. The low $\mathrm{pH}$ values were probably due to the presence of sulfur in pyrite form in some coal patches. Acidic water might also have been caused due to of the presence of $\mathrm{CO}_{2}$ and oxidation of organic compounds. The acidity in mine water may also arise due to the presence of mineral acids formed by hydrolysis of salts of some heavy metals such as ferric chloride, aluminum sulfate, manganese oxide (Environmental Protection Agency 2000). Both Sulfate and Mn concentrations were found to have a significant difference between premonsoon and monsoon seasons. This might be the reason for significant difference of acidity between premonsoon and monsoon. In some locations, the mine water was observed to be slightly alkaline, which may be due to chemical buffering and release of bicarbonate and carbonate ions or salts (Verma et al. 2012). At some other locations, the mine water was neutral in nature which could be due to the effect of calcite in coal strata and in the aquifer, precipitation of iron, and the chemical buffering effect of the water (Liu et al. 1991).
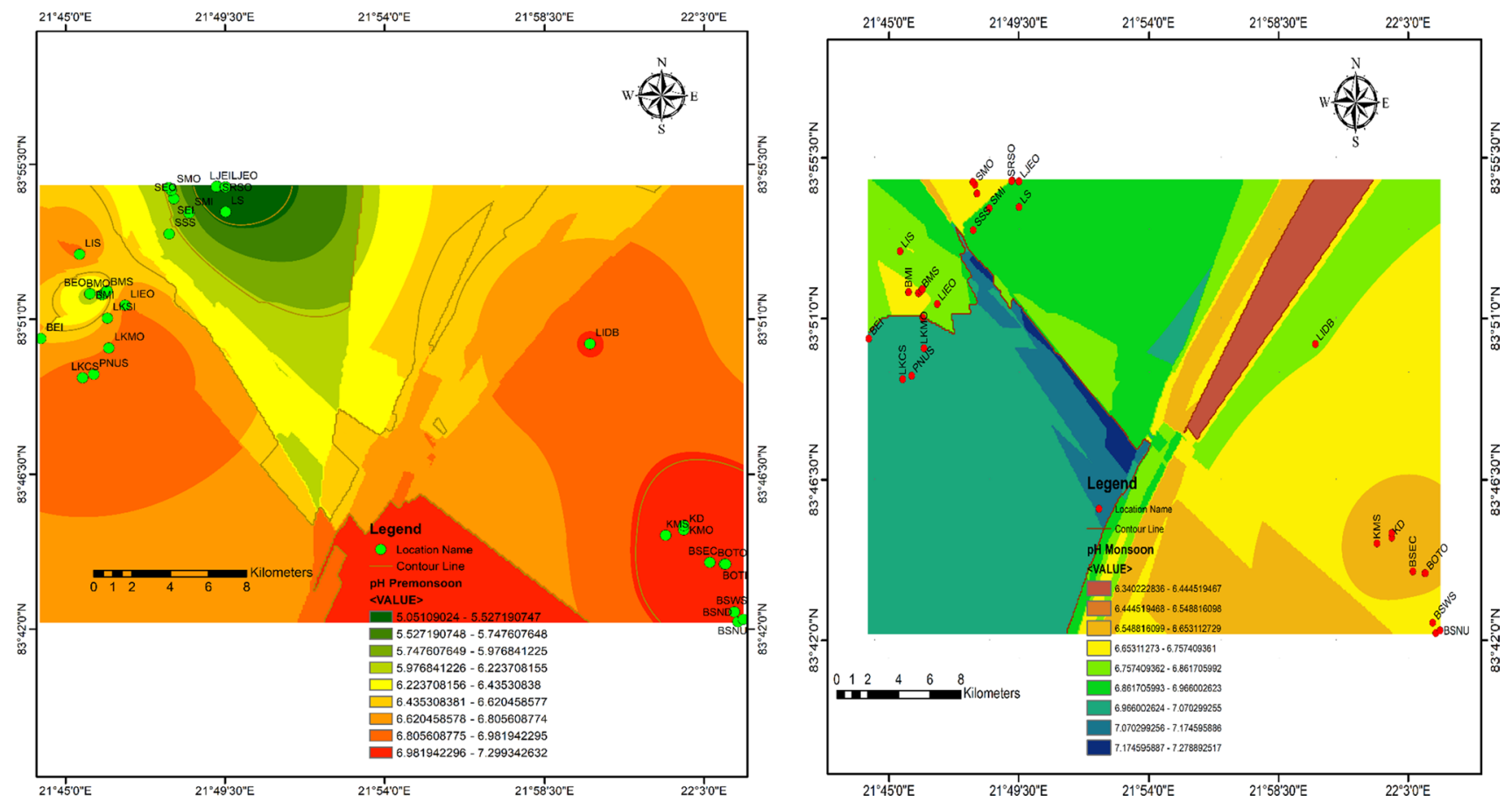

Fig. 10 Contour map of $\mathrm{pH}$ in water samples during premonsoon and monsoon season 

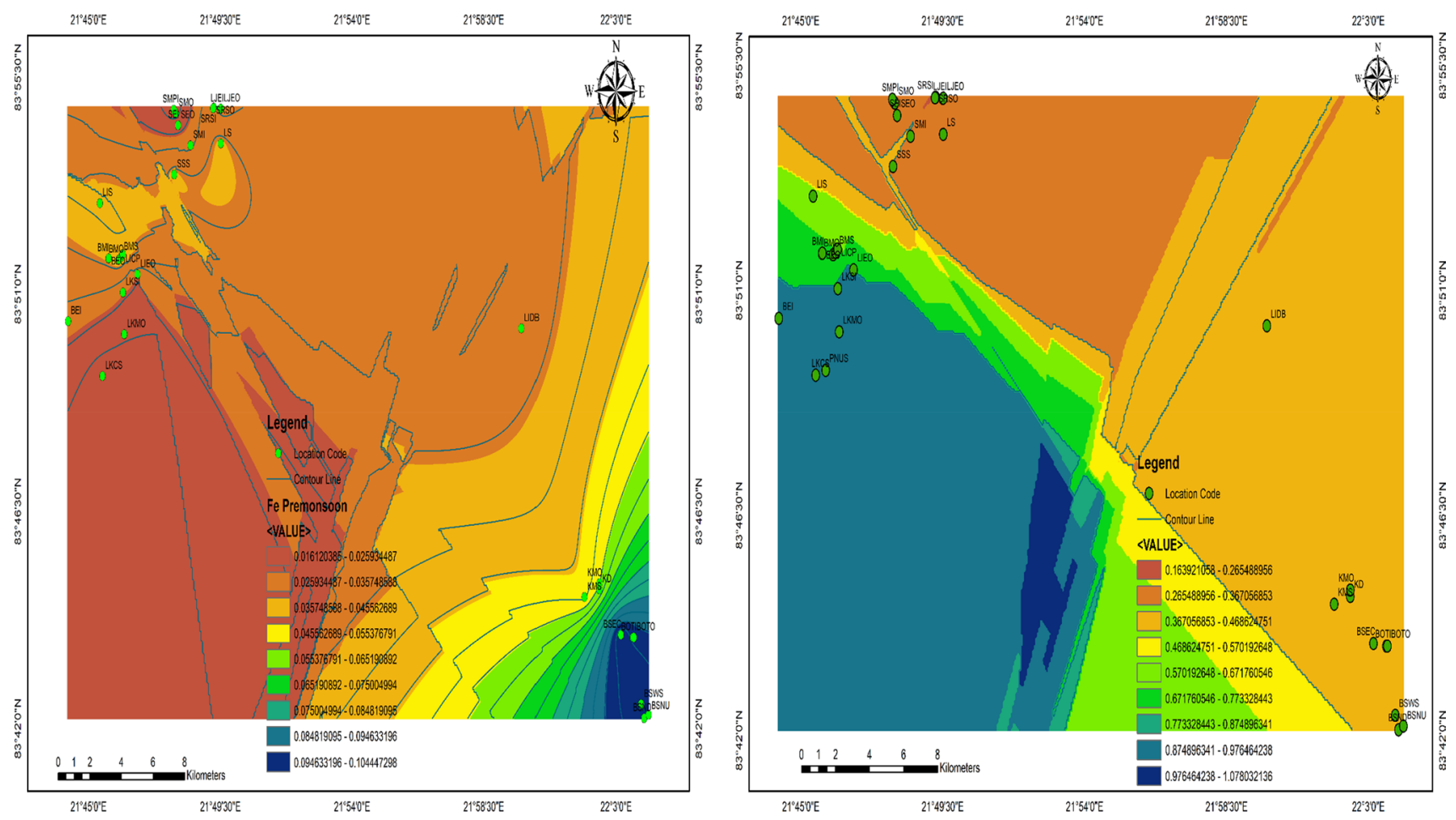

Fig. 11 Contour map for Iron concentration in water samples during premonsoon and monsoon season
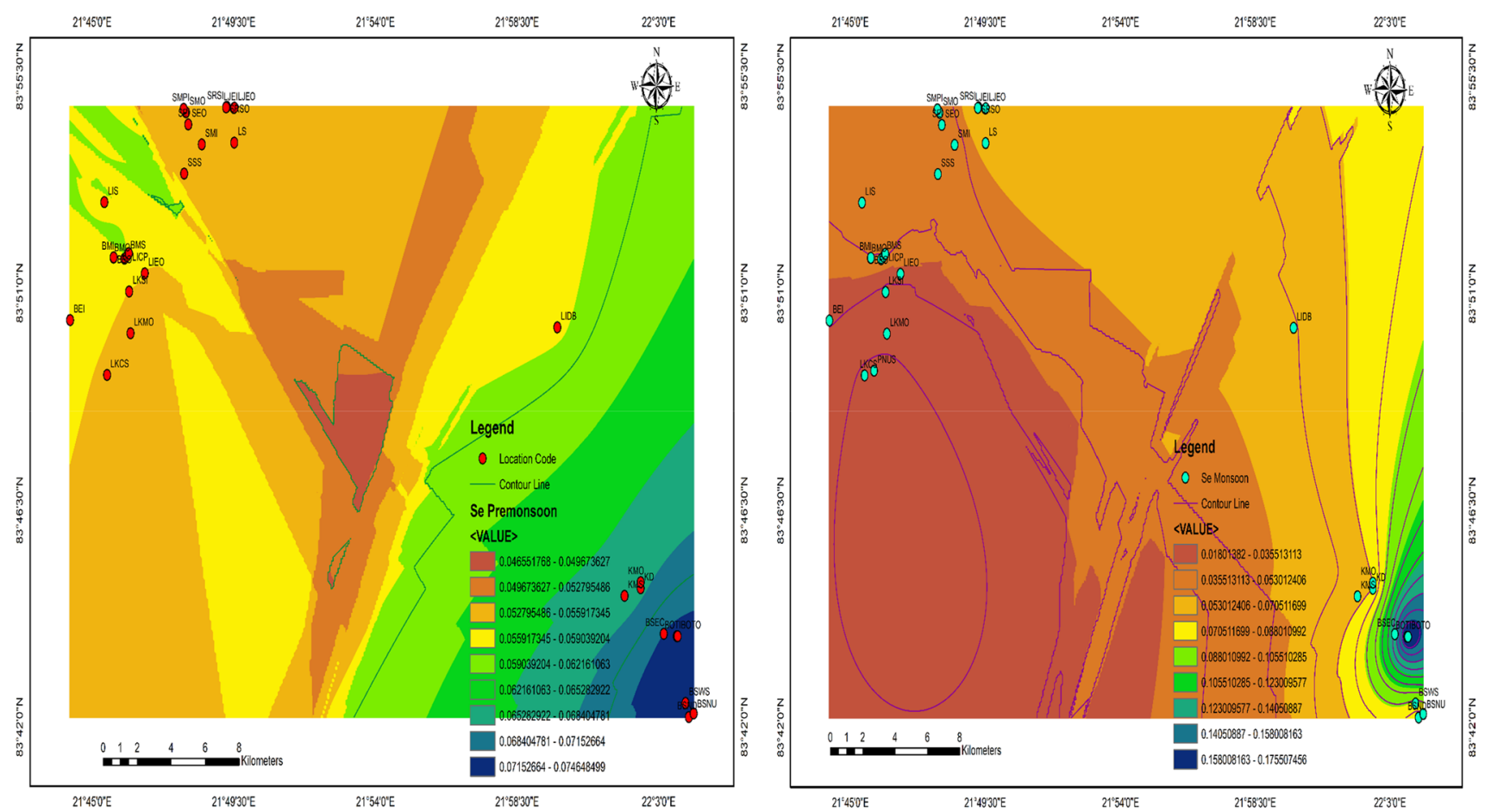

Fig. 12 Contour map for Se concentration in water samples during premonsoon and monsoon season 


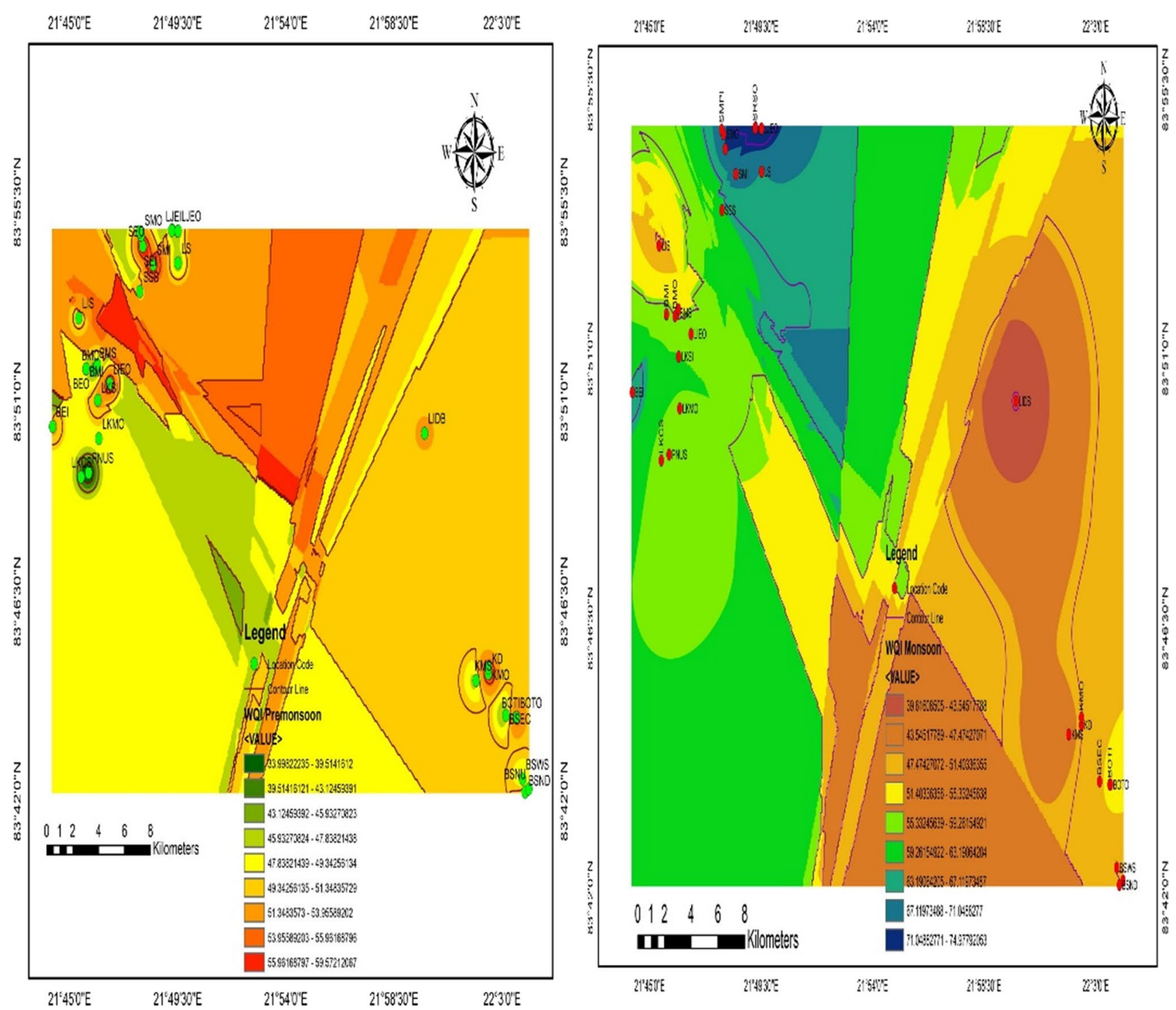

Fig. 13 Contour map of WQI in water samples during premonsoon and monsoon season

The EC values in the range of $0-250,251-750$, and 751-2250 were categorized as low saline, medium saline and high saline, respectively(Islam et al. 2016). In Ib Valley coalfield, the EC values had been found in the range between 58 to 1580 in premonsoon and 32 to 2120 in monsoon, which indicated that the water quality of the region was low to highly saline. This might be due to the ionization of salts of various compound.

\section{Turbidity}

Considerably turbid water at most of the mine locations had been recorded above the permissible limit. Turbidity of the water samples was found to be above the permissible limit with a maximum of 14 NTU in premonsoon and 1000 NTU in monsoon. Particulate substances mostly clay and silt, fine organic and inorganic compounds, soluble colored organic matter, algae and other microscopic particles in mine water might be the reason for the water to be found murky and turbid.

\section{DO, BOD and COD}

The Dissolve oxygen (DO) concentration is vital for aquatic lives in surface waters. DO concentration is governed by several factors like temperature, organic matter degradation, primary production and respiration (Paerl 2006). The concentrations of DO in the Ib valley coalfield were found to be in range of $0.19-6.95(3.08 \pm 1.99) \mathrm{mg} / \mathrm{L}$ in premonsoon and $0.2-6(3.1 \pm 2) \mathrm{mg} / \mathrm{L}$ in monsoon. The average DO in 

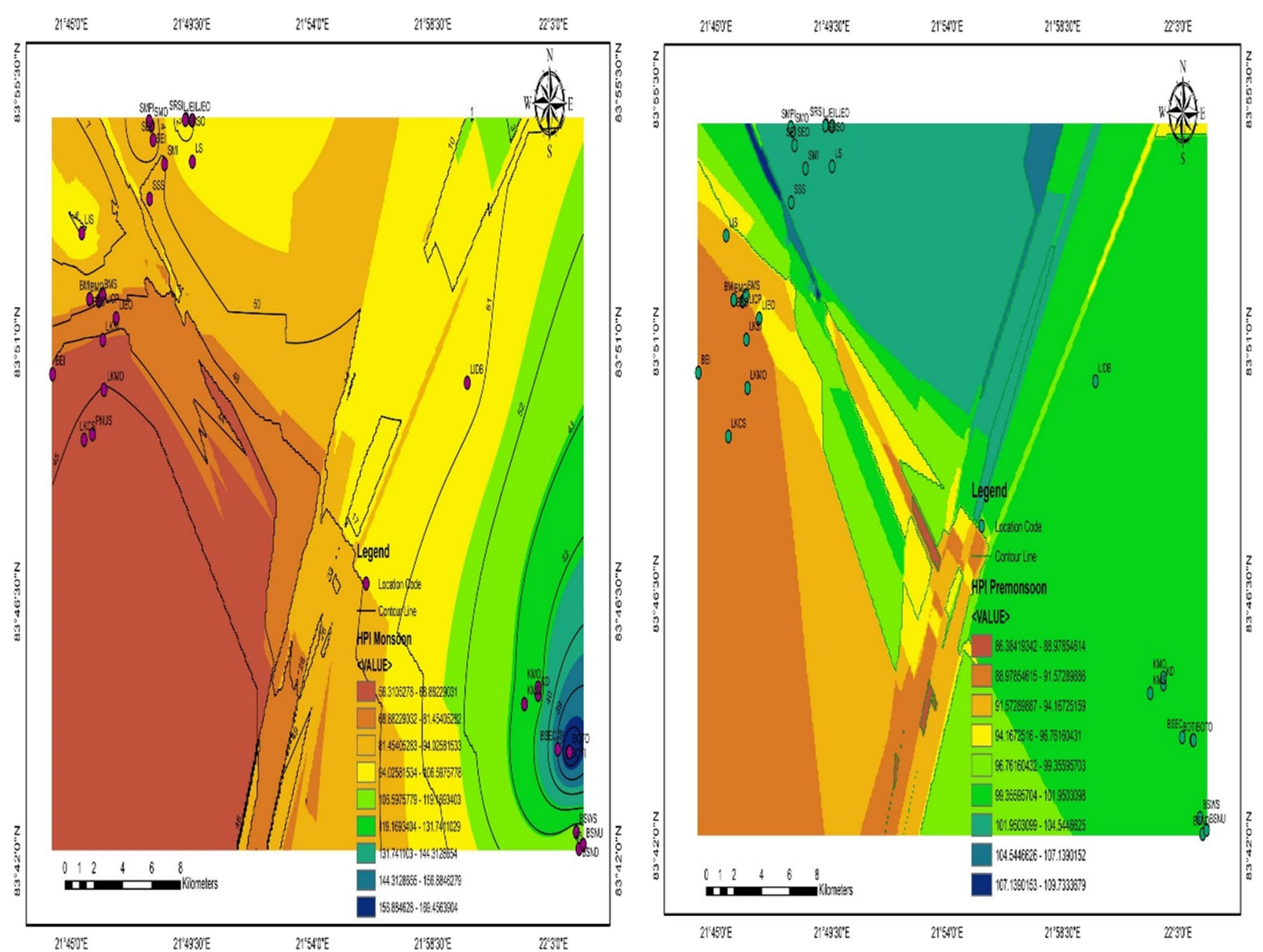

Fig. 14 Contour map of HPI concentration in water samples during premonsoon and monsoon season

both the seasons was found to be noncompliant with standards (Table 3). BOD and COD are important indicators of organic pollution in the water bodies. BOD is the amount of oxygen necessary for the metabolic activities of aerobic microorganisms during the degradation of biodegradable organic matter (Chatanga et al. 2019). The BOD concentrations were observed in the range of 10.1-73 $(33.74 \pm 20.83)$ $\mathrm{mg} / \mathrm{L}$ in premonsoon and 3.6-67.6 $(25.9 \pm 22.1) \mathrm{mg} / \mathrm{L}$ in monsoon. The average BOD concentrations were found to be very high irrespective of seasons. Chemical oxygen demand is a measure of chemical decomposition of organic and inorganic matter, dissolved or suspended substances in water. The COD indicates the contents of organics mostly, nitrites, sulfides, ferrous salts, etc. COD is expressed in terms of mass of oxygen consumed per liter of solution ( $\mathrm{Li}$ and Liu 2019). The COD concentrations were recorded in the range of $25.4-168.7(78.14 \pm 52.44) \mathrm{mg} / \mathrm{L}$ in premonsoon and 19.87-141.19 (63.56 \pm 49.61$)$ in monsoon. The average COD concentrations were found to be high across both seasons. The low DO, high BOD and COD in Ib valley coalfield might be due to coal mine and domestic wastewater discharges without proper treatment. The BOD/COD ratio is found to be varied from 0.3 to 0.58 with an average of $0.45 \pm 0.06$ in premonsoon and 0.12 to 0.63 with an average of $0.39 \pm 0.12$ in monsoon. If the BOD/COD is less than 0.6 , the wastewater is not fairly biodegradable and cannot be effectively treated biologically(Abdalla and Hammam 2014). The average BOD/COD was less than 0.6 in both seasons.

\section{TSS}

TSS was found in the range of 6 to $22.99 \mathrm{mg} / \mathrm{L}$ with an average of $13.64 \pm 4.57 \mathrm{mg} / \mathrm{L}$ in premonsoon and 21.97 to $1304.54 \mathrm{mg} / \mathrm{L}$ with an average of $353.12 \pm 264.33 \mathrm{mg} / \mathrm{L}$ in monsoon. Substantial quantities of suspended solids were recorded during monsoon. Suspended solids in coal mines originate from the mining activities mostly during excavation, surface runoff, dust and dirt from open mining areas. During monsoon, the kinetic energy of raindrops and subsequent runoff on exposed soil without vegetation cover causes 

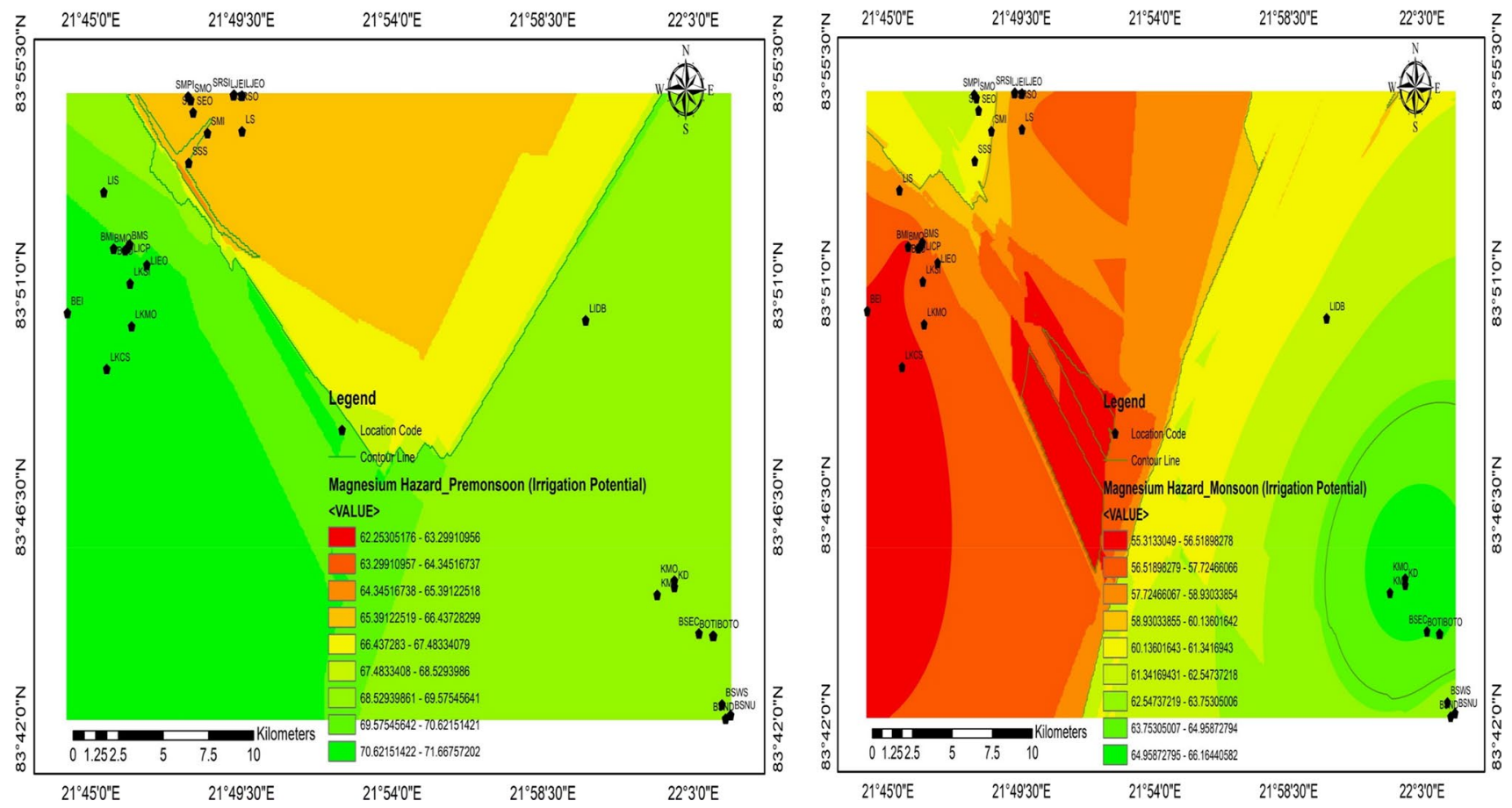

Fig. 15 Contour map of Magnesium Hazard in water samples during premonsoon and monsoon season

a substantial amount of soil to be eroded and become suspended in the runoff water. A large quantity of loose particles are generated due to mining activities, which are easily carried off by the runoff water. As the vegetation covers are taken off during mining, the exposure of bare soil by erosion and carriage of suspended solids via runoff becomes easier. It was also noted that in monsoon season, TSS concentrations in downstream samples were substantially higher compared to the upstream, demonstrating the direct impact of mining.

\section{Chloride}

Chloride was recorded in the range of $12-42.8 \mathrm{mg} / \mathrm{L}$ with an average of $29.06 \pm 9.79 \mathrm{mg} / \mathrm{L}$ in premonsoon and $17.66-33.11 \mathrm{mg} / \mathrm{L}$ with an average of $24.71 \pm 4.75 \mathrm{mg} / \mathrm{L}$ in monsoon. Chloride gets released into the aquatic bodies due to mineral disintegration, evaporation and evapotranspiration. Chloride is a minor constituent of sedimentary shakes, for example, limestone, sandstone, and shale, and in addition granitic rocks. Halite and other chloride salts being extremely soluble can easily get into the water bodies through surface runoff from mines. Warm temperature and strong light too reduce the chloride concentration in water (Sahoo et al. 2016).

\section{Fluoride}

The presence of fluoride was detected at all the sampling locations. Fluoride was found in the range of $0.1-0.54$ $(0.26 \pm 0.13) \mathrm{mg} / \mathrm{L}$ in premonsoon and $0.007-0.79$ $(0.4 \pm 0.22) \mathrm{mg} / \mathrm{L}$ in monsoon. The presence of fluoride in high concentration in water had been related to dental fluorosis (Brindha and Elango 2011) and even cancer (Peckham and Awofeso 2014), but its absence roots osteoporosis, wherein degeneration of bones and teeth happen. Fluoride pollution of water can be linked with fluoridebearing minerals in rocks from volcanic and fumarolic actions, from industrial discharges, and from precipitation as downpour or dry drop out. The disintegration of fluorite, apatite, and topaz from zonal bedrocks prompts high fluoride concentration in surface water and groundwater.

\section{Sulfate}

Sulfate was observed in the range of $10.82-177.97 \mathrm{mg} / \mathrm{L}$ with an average of $91.56 \pm 44.08 \mathrm{mg} / \mathrm{L}$ in premonsoon and $52.11-493.23 \mathrm{mg} / \mathrm{L}$ with an average of $155.47 \pm 87.15 \mathrm{mg} / \mathrm{L}$ in monsoon. Overburden dumps generally have some lowgrade coal with high sulfide mineral content such as pyrite, sphalerite, galena, chalcopyrite and pyrrhotite. Sulfate from these minerals might have been leached out with surface runoff. Moreover, Jharsuguda town is an industry hub, located in close proximity to the coalfield, and $\mathrm{SO}_{\mathrm{X}}$ in the 
atmosphere in the form of rainwater might have contributed to the sulfate concentration in water in monsoon.

\section{Nitrate}

Nitrate concentration was observed varied from 8.9 to $22.2 \mathrm{mg} / \mathrm{L}$ with an average of $15.71 \pm 3.11 \mathrm{mg} / \mathrm{L}$ in premonsoon and 3.7 to $19.9 \mathrm{mg} / \mathrm{L}$ with an average of $12.49 \pm 3.71 \mathrm{mg} / \mathrm{L}$ in monsoon. Nitrate in the coal mine water samples and nearby water bodies might be found due to the use of explosives for blasting in the mines and use of NPK fertilizers for plantation and agriculture in $\mathrm{Ib}$ valley coalfield area.

\section{Heavy metals}

Coal contains almost all the elements, whose concentration varies from parts per trillion (ppt) to greater than $50 \mathrm{wt} \%$ (Finkelman 1993). Chemical analysis of coal mine water samples revealed that selenium was present in all the samples in premonsoon as well as in monsoon. Both organic and inorganic selenium naturally occur in coal and the overburden. Selenite is found in the oxidized coal. Pyrite contains sulfidic form of selenium. Selenium in selendic form as Clausthalite $(\mathrm{PbSe})$ is also found in coal (Yudovich and Ketris 2005). On contact with water, these species of selenium are leached out in a huge amount from the waste rock into the aquatic environment. Selenium in higher concentration may cause endocrine dysfunction, chiefly synthesis of thyroid hormones, metabolism of growth hormone and insulin-like growth factor-1, damage of natural killer cells action, hepatotoxicity and gastrointestinal issues. Dermatologic impacts include nail and hair loss and dermatitis, neurotoxicity effect such as deterioration of motor neurons may result in amyotrophic lateral sclerosis, and selenium compounds show a bivalent influence in cancer, either growing or declining (Vinceti et al. 2001). Arsenic was found to be present in $24.24 \%$ of the sample in premonsoon and $26.47 \%$ in monsoon. Arsenic has a strong affinity toward sulfide minerals in coal (Coleman and Bragg 1990). Combustion of fossil fuel leads to release of arsenic into the environment. Copper occurred in all water sample in premonsoon and $50 \%$ of the water samples in monsoon. Among all the heavy metals, only copper exhibited a significant difference between both the seasons. Earlier researchers had found high concentration of copper in Indian coals (Mukherjee 1982). Discharge from mine tailing and flyash also contributes to water pollution with copper (Krishnan 1995). Sorption of copper on suspended material increases in high $\mathrm{pH}$ condition (Aller et al. 1987). Coal ash contains a high amount of nickel (Mukherjee et al. 1982). In this study, Ni was found in $57.57 \%$ and $70 \%$ of the sample in premonsoon and monsoon, respectively. Nickel gets mobilized in the environment due to the burning of fossil fuel (Dara 1993). Nickel concentration in water increases under reducing condition in the presence of organic matter (Lu and Chen 1977). Iron was present in 93.93\% of the samples in premonsoon and $100 \%$ in monsoon. Iron contamination in mine water may be attributed to oxidation of pyrite. Excess iron may cause cirrhosis of the liver and heart failure in human beings. Zinc is mostly found in coal waste and gets into the water bodies through surface runoff from the waste dump. The major geological source of cadmium is coal and overburden. Cadmium was present in all the samples in premonsoon and $88.23 \%$ of the sample in monsoon and was found mostly above the permissible limit. Mercury was not found in any of the collected samples during both seasons.

As per Heavy Metal Pollution Index (HPI), Degree of Contamination $(\mathrm{Cd})$ and Heavy metal evaluation index (HEI), medium degree of pollution were exhibited by $51.52 \%, 30.30 \%$ and $45.45 \%$ samples in premonsoon and $20.59 \%, 35.29 \%$ and $26.47 \%$ samples in monsoon. Whereas, $5.88 \%, 2.94 \%$ and $5.88 \%$ samples caused high degree of pollution in monsoon and $15.15 \%$ samples caused high degree of pollution with respect to $\mathrm{Cd}$ in premonsoon. Water Quality Index (WQI) revealed that $39.39 \%$ and $35.29 \%$ samples belonged to poor water quality category in premonsoon and monsoon, respectively. Basundhara nallah upstream and downstream water (Fig. 3) exhibited a water quality index of 43.66 and 58.91 in premonsoon season and 38.30 and 56.33 in monsoon season, respectively. Further, Basundhara nallah downstream was observed to have higher HPI of 113.03 than the upstream HPI of 98.43 in premonsoon. This clearly indicated that mine drainage from Basundhara OCP contributed to increasing of pollution load in the Basundhara nallah. Basundhra river downstream near Kulda OCP (Fig. 3) had higher WQI than basundhara nallah upstream. Although heavy metals are present in the water; the HPI, $\mathrm{Cd}$ and HEI values indicated low heavy metal pollution in Basundhra river. Lilari nallah upstream (Fig. 2) point had WQI, HPI, HEI and Cd values lower than the downstream near Belpahar OCP and Lakhanpur OCP (Fig. 2). This might be due to mine discharge from both Belpahar and Lakhanpur OCPs. Water sample from Puljari nallah could not be taken during the premonsoon season as it was dry. The upstream sample was only collected in the monsoon as the downstream was inaccessible. The WQI for this sample was found to be 44.44, which showed it to be good. Moreover, the HPI, Cd and HEI values exhibited low pollution due to heavy metals.

\section{Irrigation potential of mine water}

The analysis results of irrigation potential of mine water are presented in Table 9. Sodium can react with soil to decrease its

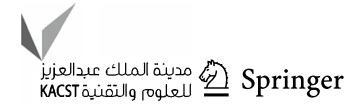




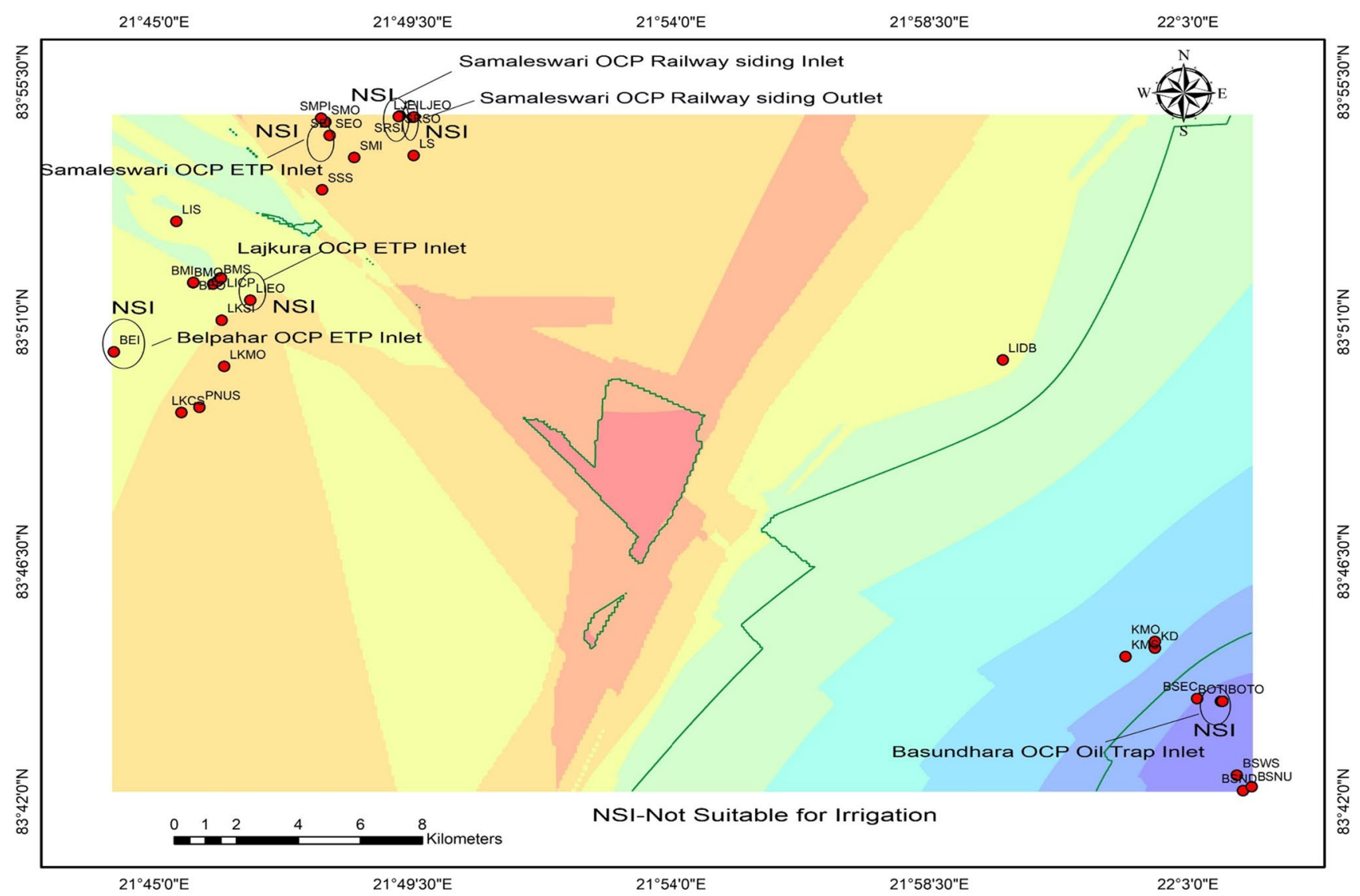

Fig. 16 Ib valley Coalfield map showing locations not suitable for Irrigation

Table 9 Assessment of irrigation potential of mine water based on analysis of Na\%, SAR, RSC, EC, MH and PI

\begin{tabular}{|c|c|c|c|c|c|c|c|}
\hline \multirow[t]{2}{*}{ Parameter } & \multirow[t]{2}{*}{ Premonsoon } & \multirow[t]{2}{*}{ Monsoon } & \multicolumn{5}{|c|}{ Standards for Irrigation IS 11624 (1986) } \\
\hline & & & Excellent & Good & Medium & $\mathrm{Bad}$ & Very bad \\
\hline $\mathrm{Na} \%$ & $\begin{array}{l}12.1-33.22 \\
\quad(22.6 \pm 5.68)\end{array}$ & $\begin{array}{c}12.37-45.19 \\
(25.09 \pm 7.89)\end{array}$ & $<20$ & $20-40$ & $40-60$ & $60-80$ & $>80$ \\
\hline SAR & $\begin{array}{l}0.17-1.01 \\
\quad(0.46 \pm 0.22)\end{array}$ & $\begin{array}{l}0.19-1.44 \\
\quad(0.61 \pm 0.29)\end{array}$ & $<10$ & $10-18$ & $18-26$ & $>26$ & $>26$ \\
\hline RSC & $\begin{array}{r}-3.54--0.82 \\
(-2.02 \pm 0.7)\end{array}$ & $\begin{array}{l}-6.43-0.86 \\
(-2.86 \pm 1.13)\end{array}$ & $<1.25$ & $1.25-2.0$ & $2.0-2.5$ & $2.5-3.0$ & $>3.0$ \\
\hline $\mathrm{EC}(\mu \mathrm{S} / \mathrm{cm})$ & $\begin{array}{l}58-1580 \\
\quad(430.82 \pm 370.38)\end{array}$ & $\begin{array}{l}32-2120 \\
\quad(406.62 \pm 472.94)\end{array}$ & $<250$ & $250-750$ & $750-2250$ & $2250-4000$ & $>4000$ \\
\hline MH & $\begin{array}{l}49.79-75.89 \\
(68.45 \pm 5.19)\end{array}$ & $\begin{array}{l}46.31-75.36 \\
\quad(60.48 \pm 7.11)\end{array}$ & $<50$ & - & - & - & - \\
\hline PI (\%) & $\begin{array}{l}31.28-73.44 \\
\quad(54.44 \pm 11.84)\end{array}$ & $\begin{array}{l}16.66-73.39 \\
(40.26 \pm 14.17)\end{array}$ & $\begin{array}{l}>75 \% \text { maximum } \\
\text { permeability } \\
\text { (Class } 1)\end{array}$ & $\begin{array}{l}\text { 75-25\% maximum } \\
\text { permeability } \\
\text { (Class 2) }\end{array}$ & & $\begin{array}{l}25 \% \text { maximum } \\
\text { permeability } \\
\text { (Class 3) }\end{array}$ & \\
\hline
\end{tabular}

degree of permeability (Todd 1980). Generally, little difficulties arise when SP values are less than $20 \%$. When $\mathrm{Na} \%$ more than $20 \%$, permeability will reduce. The finer the soil texture is and the more the organic matter amounts are and the bigger 
the effect of sodium on infiltration of water and aeration (Joshi 2009). The $\mathrm{Na} \%$ was found to be in the range of 12.1-33.22 with an average of $22.6 \pm 5.68$ in premonsoon and $12.37-45.19$ with an average of $25.09 \pm 7.89$ in monsoon. This showed the water quality was good with respect to $\mathrm{Na} \%$ irrigation standards IS 11624 (1986). The SAR was observed in the range of $0.17-1.01$ with an average of $0.46 \pm 0.22$ in premonsoon and 0.19 to 1.44 with an average of $0.61 \pm 0.29$ in monsoon. This revealed the water was excellent with respect to irrigation standards IS 11624 (1986). The water bodies having high RSC are highly alkaline due to high $\mathrm{pH}$. Soil irrigated with such water becomes infertile due to deposition of sodium carbonate. $\mathrm{RSC}<1.25$ is considered to be excellent for irrigation The average RSC was found as -2.02 and -2.86 in premonsoon and monsoon which was below 1.25 and therefore excellent for irrigation IS 11624 (1986). The water was good as far as EC was concerned in both seasons. The more the EC, the less water plant can take up. Usually, in water bodies, calcium and magnesium tend to maintain a steady state of equilibrium. However, more magnesium in aquatic system will reduce the plant productivity as the soil solution becomes further alkaline. The $\mathrm{MH}$ was found to be in the range of 49.79-75.89 with an average of $68.45 \pm 5.19$ in premonsoon and 46.31-75.36 with an average of $60.48 \pm 7.11$ in monsoon. The average $\mathrm{MH}$ was non-conforming to irrigation standards of less than 50 IS 11624 (1986) in both seasons. The average PI was recorded to be $54.44 \pm 11.84 \%$ in premonsoon and $40.26 \pm 14.17 \%$ in monsoon. Thus, the water belonged to the Class 2 (75-25\%) type which was good for irrigation. The mine water was good with respect to $\mathrm{Na} \%, \mathrm{EC}$ and PI, excellent with SAR and RSC, but poor with $\mathrm{MH}$. Overall, the mine water can be used for irrigation with very little or no treatment except for six locations such as samaleswari OCP railway siding inlet and outlet, Basundhara OCP oil trap inlet, Samaleswari OCP ETP Inlet, Lajkura OCP ETP Inlet and Belpahar OCP ETP Inlet (Fig. 16).

\section{Conclusion}

The water of the Ib valley coalfield is slightly acidic to neutral to slightly alkaline in nature except for samaleswari OCP railway siding inlet ( $\mathrm{pH}-3.77$ in premonsoon) and outlet ( $\mathrm{pH}-4.55$ in premonsoon and 3.05 in monsoon) and Basundhara OCP oil trap inlet (pH-3.6 in monsoon).

In premonsoon, parameters which are found noncompliant to the standards are $\mathrm{pH}$, TSS, Turbidity, DO, BOD, COD, Magnesium, Cadmium, Selenium, Nickel and Aluminum. In monsoon, noncompliant parameters include pH, TSS, Turbidity, DO, BOD, COD, Iron, Cadmium, Selenium, Nickel and Aluminum. Iron is found above the standards in monsoon season only. Magnesium is observed above the standard in premonsoon season only.
The average BOD/COD of less than 0.6 in both seasons indicates Ib valley coalfield water is not fairly biodegradable.

The major ions present in water are found to be Calcium-Magnesium-Sulfate-Chloride.

Water Quality Index (WQI) revealed that 39.39\% and $35.29 \%$ samples belong to poor water quality category in premonsoon and monsoon. Moderate degree of pollution has been recorded in water bodies of $\mathrm{Ib}$ valley coalfield as per Heavy Metal Pollution Index (HPI), Degree of Contamination (Cd) and Heavy metal evaluation index (HEI) and is not suitable for drinking.

The mine water is good with respect to $\mathrm{Na} \%, \mathrm{EC}$ and $\mathrm{PI}$, excellent with SAR and RSC, but poor with MH. Overall, the mine water can be used for irrigation with very little or no treatment except for six locations such as samaleswari OCP railway siding inlet and outlet, Basundhara OCP oil trap inlet, Samaleswari OCP ETP Inlet, Lajkura OCP ETP Inlet and Belpahar OCP ETP Inlet.

Mine drainage from Basundhara OCP contributes to increasing of pollution load in the Basundhara nallah. Basundhra river downstream near Kulda OCP has higher WQI than basundhara nallah upstream. Although heavy metals are present in the water, the HPI, Cd and HEI values indicate low heavy metal pollution in Basundhra nallah and river.

Lilari nallah upstream point has WQI, HPI, HEI and Cd values lower than the downstream near Belpahar OCP and Lakhanpur OCP. This may be due to mine discharge from both Belpahar and Lakhanpur OCPs.

Mining activities, surface runoff, coal burning, atmospheric precipitation, weathering, leaching, industrial activities and anthropogenic activities could be mostly controlling the water chemistry of the Ib valley Coalfield.

Acknowledgements The authors are thankful to the Director, National Institute of Technology, Rourkela. The authors thank Prof. R. K. Patel, Associate Professor, Department of Chemistry, NIT, Rourkela; Dr. S. K. Swain, Scientific Officer, BIT Mesra, Ranchi; for their help in carrying out some of the experiments. We also thank the authorities of MCL, Sambalpur for their support for carrying out the study. We thank Er S. K.Srivastava, former AGM (Environment); Dr. S. Jha, former $\mathrm{Sr}$ Engineer (Environment) for their guidance. The authors thank Er D. K. Patra, Area Environment Officer of Ib Valley Area, MCL for his help in the collection of water samples.

Funding This research did not receive any specific grant from funding in the public, commercial, or not-for-profit sectors.

\section{Declaration}

Conflict of interest All authors have participated in (a) conception and design, or analysis and interpretation of the data; (b) drafting the article or revising it critically for important intellectual content; and (c) approval of the final version. This manuscript has not been submitted to, nor is under review at, another journal or other publishing venue.

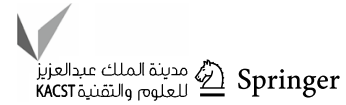


The authors have no affiliation with any organization with a direct or indirect financial interest in the subject matter discussed in the manuscript. On behalf of all authors, the corresponding author states that there is no conflict of interest.

Open Access This article is licensed under a Creative Commons Attribution 4.0 International License, which permits use, sharing, adaptation, distribution and reproduction in any medium or format, as long as you give appropriate credit to the original author(s) and the source, provide a link to the Creative Commons licence, and indicate if changes were made. The images or other third party material in this article are included in the article's Creative Commons licence, unless indicated otherwise in a credit line to the material. If material is not included in the article's Creative Commons licence and your intended use is not permitted by statutory regulation or exceeds the permitted use, you will need to obtain permission directly from the copyright holder. To view a copy of this licence, visit http://creativecommons.org/licenses/by/4.0/.

\section{References}

Abdalla KZ, Hammam G (2014) Correlation between biochemical oxygen demand and chemical oxygen demand for various wastewater treatment plants in Egypt to obtain the biodegradability indices. Int J Sci Basic Appl Res 13(1):42-48

Aller L, Lehr JH, Petty R, Bennett T (1987) DRASTIC: a standardized system to evaluate groundwater pollution potential using hydrogeologic settings. National Water Well Association, Worthington, Ohio, United States of America, pp 38-57

APHA (2012) Standard methods for the examination of water and wastewater, 22nd edn. American Public Health Association, Washington, DC

Ministry of Coal (2016-2017). Annual Report, Govt. of India

Balakrishnan A, Ramu A (2016) Evaluation of heavy metal pollution index (HPI) of ground water in and around the Coastal Area of Gulf of Mannar Biosphere and Palk Strait. J Adv Chem Sci 2(3):331-333

Brindha K, Elango L (2011) Fluoride in groundwater: causes, implications and mitigation measures. Fluoride properties, applications and environmental management, pp 111-136

Bureau of Indian Standards (BIS) (1986) Indian standard IS: 11614. Guidelines for the quality of Irrigation water

Bureau of Indian Standards (BIS) (2012) Indian standard IS: 10500. Drinking Water Specification. Second Revision

Central Ground Water Board (2013) Groundwater Information booklet of Jharsuguda District. Ministry of Water Resources, Govt. of India

Chatanga P, Ntuli V, Mugomeri E, Keketsi T, Chikowore NVT (2019) Situational analysis of physico-chemical, biochemical and microbiological quality of water along Mohokare River, Lesotho. Egypt J Aquat Res 45(1):45-51

Coleman SL, Bragg LJ (1990) Distribution and mode of occurrence of arsenic in coal. Geol Soc Am Spec Papers 248:13-26

Dara SS (1993) A textbook of environmental chemistry and pollution control. S. Chand, New Delhi

Edet AE, Offiong OE (2002) Evaluation of water quality pollution indices for heavy metal contamination monitoring. A study case from Akpabuyo-Odukpani area, Lower Cross River Basin (southeastern Nigeria). GeoJournal 57(4):295-304

Edmond JM, Palmer MR, Measures CI, Grant B, Stallard RF (1995) The fluvial geochemistry and denudation rate of the Guayana Shield in Venezuela, Colombia, and Brazil. Geochim Cosmochim Acta 59(16):3301-3325
Environmental Protection Agency, U.S. (2000) Drinking water standards and health advisories. http://www.epa.gov/OST

Finkelman RB (1993) Trace and minor elements in coal. Organic geochemistry. Springer, Boston, pp 593-607

Goswami S, Das M, Guru BC (2006) Permian biodiversity of Mahanadi Master Basin, Orissa, India and their environmental countenance. Acta Palaeobotanica 46(2):101-118

Huh Y, Panteleyev G, Babich D, Zaitsev A, Edmond JM (1998) The fluvial geochemistry of the rivers of eastern Siberia: II Tributaries of the Lena, Omoloy, Yana, Indigirka, Kolyma, and Anadry draining the collisional/accretionary zone of the Verkhoyansk and Cherskiy ranges. Geochim Cosmochim Acta 62(12):2053-2075. https://doi.org/10.1016/S0016-7037(98)00127-6

Islam SMDU, Majumder RK, Uddin MJ, Khalil MI, Ferdous Alam M (2016) Hydrochemical characteristics and quality assessment of groundwater in Patuakhali District, Southern Coastal Region of Bangladesh. Exposure and Health 9(1):1-18. https://doi.org/10. 1007/s12403-016-0221-y

Joshi D, M., Kumar, A., and Agrawal, N. (2009) Assessment of the irrigation water quality of river Ganga in Haridwar District. Rasayan J Chem 2(2):285-292

Krishnan K (1995) Fundamentals of Environmental Pollution. S Chand, New Delhi

Li D, Liu S (2019) Chapter 8-Water quality detection for lakes. In: Li D, Liu S (eds) Water quality monitoring and management. Academic Press, London, pp 221-231. https://doi.org/10.1016/ B978-0-12-811330-1.00008-9

Liu Z, Yuan D, Shen Z (1991) Effect of coal mine waters of variable pH on springwater quality: A case study. Environ Geol Water Sci 17(3):219-225. https://doi.org/10.1007/BF01701702

Loska K, Wiechuła D, Korus I (2004) Metal contamination of farming soils affected by industry. Environ Int 30(2):159-165

Lu JCS, Chen KY (1977) Migration of trace metals in interfaces of seawater and polluted surficial sediments. Environ Sci Technology 11(2):174-182

Mondal GC, Singh AK, Singh TB (2012) Hydrogeochemistry and quality assessment of mine water of West Bokaro coalfields. Hazaribag 3(945):3499-3512

Mukherjee KN (1982) Trace element studies in the major Tertiary and Gondwana coalfields of India. Geological Survey of India

Ministry of Environment, Forest and Climate Change (2015) Primary Water Quality Criteria for Bathing Purposes. Government of India, New Delhi

Odisha State Pollution Control Board (2010) Action plan for abatement of pollution in critically polluted industrial clusters, Ib valleyjharsuguda area, pp 1-83

Paerl HW (2006) Assessing and managing nutrient-enhanced eutrophication in estuarine and coastal waters: Interactive effects of human and climatic perturbations. Ecol Eng 26(1):40-54

Pathak V, Banerjee A, K. (1992) Mine water pollution studies in Chapha incline, Umaria coalfield, eastern Madhya Pradesh, India. Mine Water Environ 11(2):27-35

Peckham S, Awofeso N (2014) Water fluoridation: A critical review of the physiological effects of ingested fluoride as a public health intervention. Sci World J 293:1-10. https://doi.org/10.1155/2014/ 293019

Prasad B, Bose JM (2001) Evaluation of the heavy metal pollution index for surface and spring water near a limestone mining area of the lower himalayas. Environ Geol 41(1-2):183-188. https:// doi.org/10.1007/s002540100380

Provisional Coal Statistics (2013-2014) Coal Controller's organization, Ministry of Coal, Govt. of India

Sahoo M, Mahananda MR, Seth P (2016) Physico-chemical analysis of surface and groundwater around talcher coal field. J Geosci Environ Protect 4:26-37 
Senapaty A, Behera P (2015) Stratigraphic control of petrography and chemical composition of the lower gondwana coals, Ib-Valley Coalfield, Odisha, India. J Geosci Environ Protect 3(4):56-66. https://doi.org/10.4236/gep.2015.34007

Singh G (1988) Impact of coal mining on mine water quality. Int J Mine Water 7(3):49-59

Singh AK, Mahato MK, Neogi B, Tewary BK, Sinha A (2011) Environmental geochemistry and quality assessment of mine water of Jharia coalfield, India. Environ Earth Sci 65:49-65

Tiwari AK, Singh PK, Singh AK, De Maio M (2016) Estimation of heavy metal contamination in groundwater and development of a heavy metal pollution index by using GIS technique. Bull Environ Contam Toxicol 96(4):508-515. https://doi.org/10.1007/ s00128-016-1750-6

Tiwary RK, Dhar BB (1994) Environmental pollution from coal mining activities in Damodar river basin, India. Mine Water Environ 13:1-10

Todd DK (1980) Groundwater hydrology, 2nd (edn). John Wiley and Sons, New York, p 535

Verma P, Chandawat D, Gupta U, Solanki H (2012) Water quality analysis of an organically polluted lake by investigating different physical and chemical parameters. Int J Res Chem Environ 2(1):105-111

Vinceti M, Wei ET, Malagoli C, Bergomi M, Vivoli G (2001) Adverse health effects of selenium in humans. Rev Environ Health 16(4):233-252

World Health Organizatio (WHO) (2011) Geneva. Guidelines for Drinking Water Quality. 4th edn

Yogendra K, Puttaiah ET (2008) Determination of water quality index and suitability of an Urban waterbody in Shimoga Town, Karnataka. In: Proceedings of Taal: the 12th World Lake conference, pp 342-346

Yudovich YE, Ketris MP (2005) Selenium in coal: a review. Int J Coal Geol 61(3-4):141-196. https://doi.org/10.1016/j.coal.2004.09.003

Publisher's Note Springer Nature remains neutral with regard to jurisdictional claims in published maps and institutional affiliations. 